Review

\title{
Therapeutic Use of Valproic Acid and All-Trans Retinoic Acid in Acute Myeloid Leukemia-Literature Review and Discussion of Possible Use in Relapse after Allogeneic Stem Cell Transplantation
}

\author{
Øystein Bruserud ${ }^{1,2}$ * ${ }^{\text {, Galina Tsykunova }}{ }^{2}$, Maria Hernandez-Valladares ${ }^{3}$ (D), Hakon Reikvam ${ }^{1,2}$ (D) \\ and Tor Henrik Anderson Tvedt ${ }^{2}$ \\ 1 Department of Clinical Science, University of Bergen, N-5021 Bergen, Norway; hakon.reikvam@uib.no \\ 2 Department of Medicine, Haukeland University Hospital, N-5021 Bergen, Norway; \\ galina.tsykunova@helse-bergen.no (G.T.); tor.henrik.anderson.tvedt@helse-bergen.no (T.H.A.T.) \\ 3 The Proteomics Facility of the University of Bergen (PROBE), University of Bergen, N-5021 Bergen, Norway; \\ maria.hernandez-valladares@uib.no \\ * Correspondence: oystein.bruserud@helse-bergen.no
}

Citation: Bruserud, Ø.; Tsykunova, G.; Hernandez-Valladares, M.; Reikvam, H.; Tvedt, T.H.A Therapeutic Use of Valproic Acid and All-Trans Retinoic Acid in Acute Myeloid Leukemia-Literature Review and Discussion of Possible Use in Relapse after Allogeneic Stem Cell Transplantation. Pharmaceuticals 2021, 14, 423. https://doi.org/ $10.3390 / \mathrm{ph} 14050423$

Academic Editor: Shunsuke Kondo

Received: 29 March 2021

Accepted: 26 April 2021

Published: 2 May 2021

Publisher's Note: MDPI stays neutral with regard to jurisdictional claims in published maps and institutional affiliations.

Copyright: (c) 2021 by the authors. Licensee MDPI, Basel, Switzerland. This article is an open access article distributed under the terms and conditions of the Creative Commons Attribution (CC BY) license (https:// creativecommons.org/licenses/by/ $4.0 /)$.

\begin{abstract}
Even though allogeneic stem cell transplantation is the most intensive treatment for acute myeloid leukemia (AML), chemo-resistant leukemia relapse is still one of the most common causes of death for these patients, as is transplant-related mortality, i.e., graft versus host disease, infections, and organ damage. These relapse patients are not always candidates for additional intensive therapy or re-transplantation, and many of them have decreased quality of life and shortened expected survival. The efficiency of azacitidine for treatment of posttransplant AML relapse has been documented in several clinical trials. Valproic acid is an antiepileptic fatty acid that exerts antileukemic activity through histone deacetylase inhibition. The combination of valproic acid and all-trans retinoic acid (ATRA) is well tolerated even by unfit or elderly AML patients, and low-toxicity chemotherapy (e.g., azacitidine) can be added to this combination. The triple combination of azacitidine, valproic acid, and ATRA may therefore represent a low-intensity and low-toxicity alternative for these patients. In the present review, we review and discuss the general experience with valproic acid/ATRA in AML therapy and we discuss its possible use in low-intensity/toxicity treatment of post-allotransplant AML relapse. Our discussion is further illustrated by four case reports where combined treatments with sequential azacitidine/hydroxyurea, valproic acid, and ATRA were used.
\end{abstract}

Keywords: acute myeloid leukemia; valproic acid; all-trans retinoic acid; allogeneic stem cell transplantation; relapse

\section{Introduction}

Acute myeloid leukemia (AML) is an aggressive malignancy that can only be cured by intensive chemotherapy possibly followed by autologous or allogeneic stem cell transplantation [1,2]. The median age at the time of diagnosis is 65-70 years, and the large group of elderly patients above 70-75 years of age as well as younger unfit patients cannot receive the most intensive treatment; instead, these patients usually receive various forms of leukemia-stabilizing therapy (e.g., hypomethylating treatment) or only palliative care [1]

Relapse is a common cause of death after potentially curative intensive conventional chemotherapy, and a relatively large group of patients relapse even after the most intensive treatment including allogeneic stem cell transplantation [1,2]. There are several therapeutic alternatives for patients with AML relapse and for allotransplant recipients, including conventional intensive chemotherapy possibly followed by transplantation/re-transplantation after remission induction or less intensive treatment to achieve disease stabilization [1,2]. However, many of these patients are unfit for further intensive therapy and have reduced 
quality of life, and low-toxicity treatments are probably the best alternative for such patients. Low-toxicity therapy may also be the best alternative for several patients with early relapse and high AML cell burden because these patients often have aggressive chemoresistant disease. Finally, the same low-toxicity alternatives should also be considered for other elderly or unfit patients with newly diagnosed AML, including patients with high-risk AML [3].

Several experimental and clinical studies have investigated the effects of ATRA combined with valproic acid in the treatment of AML. Important characteristics of the two drugs are summarized in Table 1 [3-18]. Additional studies are needed to further characterize the possible mechanisms for interactions between the two drugs at the cellular level, especially whether such interactions differ between patients and depend on karyotype and/or molecular genetic abnormalities.

Table 1. Important characteristics of valproic acid and all-trans retinoic acid (ATRA) [3-18].

\begin{tabular}{|c|c|c|}
\hline & Valproic Acid & ATRA \\
\hline Chemical classification & Branched short-chain fatty acid & Vitamin A derivative/retinoid \\
\hline Molecular target & $\begin{array}{l}\text { Regulates transcription through inhibition of } \\
\text { histone deacetylation and therefore increased gene } \\
\text { transcription. HDACs are grouped into class I } \\
\text { (HDACs } 1 / 2 / 3 / 8 \text { ), class II (HDACs } \\
4 / 5 / 6 / 7 / 9 / 10 \text { ), class III (the sirtuins SIRT1-7), and } \\
\text { class IV (only HDAC11). Valproic acid inhibits } \\
\text { class I and class II HDACs, but HDACs } 9 / 11 \text { are } \\
\text { activated and HDACs } 6 / 8 / 10 \text { are not affected. }\end{array}$ & $\begin{array}{l}\text { The retinoic acid receptors (RARs) and retinoid } \\
\text { X receptors (RXRs) are ligand-activated nuclear } \\
\text { receptors. ATRA is a high-affinity activating } \\
\text { ligand of the three RAR } \alpha / \beta / \gamma \text { receptors and is } \\
\text { involved in the transcriptional regulation of } \\
\text { hundreds of genes. }\end{array}$ \\
\hline
\end{tabular}

Altered protein acetylation, including altered

Cellular effects histone acetylation and altered acetylation of many other cellular proteins including cytoplasmic proteins

Valproic acid seems to influence the

Possible interactions at the cellular level differentiation-inducing effect of ATRA; it also increases aldehyde dehydrogenase activity and may therefore have effects on vitamin A metabolism.
Altered transcriptional regulation mediated by its binding to the nuclear RAR receptors

There is a molecular crosstalk between HDACs/histone acetylases and ATRA; ATRA also influences gene expression through epigenetic modulation.
Valproic acid seems to stimulate stem cell proliferation. Experimental studies suggest that it upregulates genes important for myelomonocytic differentiation but inhibits expression of genes important for erythroid differentiation.

Drug-induced cytopenias are usually dose-dependent and reversible.
Effects on normal hematopoiesis
Altered serum levels of several amino acid and fatty acid metabolites
A majority of studies suggest that ATRA promotes the activity of hematopoietic stem cells and regulates differentiation of hematopoietic progenitor cells.

Systemic metabolic effect

Administration

Monitoring of doses

Oral or intravenous

Defined therapeutic serum levels make monitoring possible

$$
\text { Epilepsy, depression }
$$

Mainly phase I/II studies of AML-stabilizing treatment, often in combination with ATRA
Altered serum levels of several amino acid and fatty acid metabolites

Oral

Dosing based on body surface area
Accepted indication

Previous clinical studies in non-APL variants of AML
Phase I/II clinical studies of AML stabilizing treatment and randomized clinical studies in combination with intensive chemotherapy 
Valproic acid is a fatty acid that is used as an antiepileptic drug; it also has antiAML effects probably due to its function as a histone deacetylase inhibitor and a systemic metabolic modulator (Table 1) [3,5]. Its side effects are well characterized, and severe toxicity is uncommon, dose-dependent, and reversible [3]. All-trans retinoic acid (ATRA) is widely used in the treatment of acute promyelocytic leukemia (APL), but it may also have antileukemic effects at least for certain patients with non-APL variants of AML (Table 1) [4]. Valproic acid has therefore been combined with ATRA in several clinical studies of unfit or elderly patients with non-APL AML [3]. Further investigation of this dual drug combination is also encouraged by the authors of a recent randomized clinical study who combined hypomethylating therapy with valproic acid and ATRA [19]. In this article, we review the scientific basis for and discuss whether ATRA/valproic acid should be further investigated as a possible part of leukemia-stabilizing treatments for elderly or unfit patients with non-APL variants of AML, including patients with leukemia relapse after allogeneic stem cell transplantation.

\section{Experimental and Clinical Studies of Valproic Acid in Non-APL Variants of AML \\ 2.1. Experimental Studies of Valproic Acid Effects on AML Cells}

The antileukemic effects of valproic acid wer investigated in several previous studies. Studies in a murine xenograft model based on the Kasumi- 1 AML cell line with the RUNX1-RUNX1T1 fusion oncogene (i.e., $\mathrm{t}(8 ; 21)$ translocation) suggest that valproic acid upregulates histone acetylation in the $p 21$ promoter region, leading to increased p21 expression, suppressed phosphorylation of the retinoblastoma protein, and finally induction of G0/G1 arrest [20]. This is possibly due to histone deacetylase (HDAC) 1 inhibition with relocation of this enzyme from the nuclear to the perinuclear region [21]. At the same time, histone $\mathrm{H} 3$ and $\mathrm{H} 4$ hyperacetylation causes transcriptional reactivation of genes that have been silenced by the fusion protein. The p21 upregulation caused by in vivo valproic acid therapy was also observed in primary AML cells without RUNX1-RUNX1T1 fusion [22]. However, additional mechanisms may contribute to the antiproliferative and proapoptotic effects of valproic acid. First, the hippo signaling pathway is important for regulation of proliferation and apoptosis, and altered signaling through this pathway (possibly due to the induction of RASSF1A expression) may be an antileukemic mechanism especially in patients with normal and adverse karyotype [23]. Second, valproic acid in combination with interferon (IFN)- $\alpha$ alters the activation/phosphorylation of Akt, ERK1/2, p38, and p53 [24]. Third, a small study suggested that the CXCR4 protein level is reduced by valproic acid at least for certain patients and especially for AML cells that do not express the CD34 stem cell marker [25]. However, valproic acid may also increase the expression of genes involved in chemoresistance, e.g., MAKKPK2, HSP90AA1, HSP90AB1, and ACTB [24], and such effects may then counteract the other antileukemic effects.

The studies described above suggest that the antileukemic effects of valproic acid are mediated through several molecular mechanisms that possibly differ between patients. A previous in vitro study investigated patient heterogeneity with regard to the functional effects of valproic acid and three other HDAC inhibitors on primary AML cells [26]. Two main patient subsets were then identified; one subset showed a dose-dependent antiproliferative effect of various inhibitors, whereas the other subset showed growth enhancement when testing intermediate concentrations and inhibitory effects only when testing higher concentrations. These dose-dependent differences were observed in the presence of both ATRA and the hypomethylating agent decitabine, and during co-culture with AML-supporting bone marrow stromal cells. The two patient subsets differed in AML cell expression of several genes involved in the regulation of cell cycle progression, gene transcription, and DNA damage responses. In contrast, normal CD34 ${ }^{+}$hematopoietic cells showed only growth enhancement for intermediate concentrations but no antiproliferative effect with higher concentrations. Thus, AML patients are heterogeneous with regard to the effects of valproic acid on their leukemia cells, and this heterogeneity may be 
caused by differences in the balance between genes that mediate chemosensitivity versus chemoresistance, as described above.

\subsection{In Vivo Effects of Valproic Acid in AML: Clinical Studies and Animal Models}

Several studies have investigated the effects of valproic acid on AML cells derived from patients receiving valproic acid treatment. First, valproic acid monotherapy with serum concentrations corresponding to the accepted therapeutic level can induce hyperacetylation of histones $\mathrm{H} 3$ and H4, signs of myelomonocytic differentiation, and hematological improvement according to the response criteria for myelodysplastic syndromes (MDS) [27]. These responses can last for 60-180 days, at least for a subset of patients [27]. Second, another study investigated the in vivo effects of combined ATRA, valproic acid, and theophylline treatment, and pretreatment AML cells for responders and nonresponders to this triple combination differed especially in their expression of genes involved in transcriptional regulation [28]. The initial two days of ATRA monotherapy in this study decreased the expression of several HOX genes, whereas the triple combination altered the mRNA expression of DNA methyl transferase 3A (DNMT3A) (i.e., an epigenetic regulator) together with several genes involved in G-protein coupled receptor signaling, and the combination decreased the protein levels of Gata-2, NFkB p65, and Bcl-2 in AML cells [22]. Third, Rücker et al. [29] compared the gene expression profiles for AML cells derived from patients receiving intensive chemotherapy with and without additional valproic acid, and valproic acid then altered the expression of genes important for cell cycle regulation, DNA repair, and apoptosis. However, all of these studies are relatively small and the results should therefore be interpreted with great care, but they are supported by two studies in animal models. Valproic acid induced G0/G1 arrest in the murine xenograft model of the Kasumi-1 cell line [30], and valproic acid monotherapy increased the survival of immune-competent Brown Norwegian myeloid leukemia rats [31].

The effect of in vivo therapy based on ATRA plus valproic acid on the proteomic and phosphoproteomic profiles of human AML cells was investigated in a recent study [32]. This in vivo study showed that both ATRA and valproic acid had complex biological effects on the AML blasts involving several fundamental cellular functions; these observations are discussed in Section 3.6.

\subsection{Effects of Valproic Acid on Normal Hematopoietic and Bone Marrow STROMAL cells}

Experimental studies of human and murine hematopoietic stem cells show that valproic acid increases their proliferation and self-renewal capacity [11]. The drug accelerates cell cycle progression and decreases p21 levels, and these effects are possibly caused by the inhibition of GSK3 $\beta$, altered Wnt signaling, and the stabilization of $\beta$-catenin. The final effect seems to be an increased expression of HoxB4 leading to an altered regulation of stem cell self-renewal. Both $\beta$-catenin and HoxB4 can increase normal stem cell proliferation and expand the stem cell pool, and these effects may contribute to the increased levels of normal peripheral blood cell counts seen during valproic acid therapy. Valproic acid can also decrease VLA-4 expression in hematopoietic cells [33] and seems to have an antiproliferative effect on osteoblastic cells [34]; these effects together with the effects on endothelial cells (see the next section) may alter the AML supportive functions of these stromal cells in bone marrow stem cell niches.

The effect of valproic acid on AML-associated angiogenesis has been investigated in a murine xenograft model using the Kasumi-1 AML cell line [20]. Valproic acid then had an antileukemic effect with reduced expressions of proangiogenic VEGF, bFGF, and the VEGFR2 receptor, thereby leading to reduced microvessel density. The observed reduction in serum levels of the endothelium-associated proteoglycan endocan in patients receiving valproic acid may also reflect direct effects on endothelial cells with altered angioregulation [35], and this is further supported by a study on microvascular endothelial cells describing decreased proliferation and migration/tube formation together with an altered cytokine release profile by endothelial cells after exposure to valproic acid [34]. 


\subsection{Effects of Valproic Acid on Normal Immunocompetent Cells}

Valproic acid affects several immunocompetent cells, and immunosuppressive effects seem to be most common. The effects for various cell types are described more in detail below.

- $\quad \mathrm{T}$ cells. Valproic acid has strong antiproliferative but not proapoptotic effects on $\mathrm{T}$ cells in the presence of cytarabine, and it can also alter the expression of the activation markers CD38 and CD69 as well as the release of FasL, heat shock protein (HSP)90, and various cytokines [36]. The levels of regulatory T cells are increased during AML stabilizing treatment with ATRA and valproic acid [37].

- Dendritic cells. Valproic acid inhibits the release of IFN- $\alpha, \mathrm{TNF} \alpha$, and IL-6 by plasmacytoid dendritic cells; reduces their expression of costimulatory molecules as well as their capacity to promote $\mathrm{CD} 4^{+} \mathrm{T}$ cell proliferation and IFN- $\gamma$ production; and increases the proportion of anti-inflammatory IL-10-positive T cells [38]. The drug also downregulates group I CD1 expression; reduces the secretions of IL-6, IL-10, and IL-23 and TNF- $\alpha$ release; increases IL- 8 release; and reduces the capacity to promote differentiation of Th17 cells in human monocyte-derived immature dendritic cells [39]. Furthermore, a third study showed that valproic acid causes downregulation of the (co)stimulatory molecules CD40, CD80, CD83, CD86, and HLA-DR and decreases IL-10 and IL-12p70 production in mature dendritic cells [40]. These last authors also suggested that the proportion of IFN $-\gamma^{+} \mathrm{CD} 4^{+}$alloreactive T cells and the granzyme $B$ expression by $\mathrm{CD}^{+} \mathrm{T}$ cells were both decreased when these cells were cocultured with dendritic cells that were previously exposed to valproic acid. Finally, HDAC inhibition can reduce CD1a expression together with the capacity of chemokine-induced migration, immunostimulatory capacity, and cytokine release in monocyte-derived dendritic cells [41]. These last effects seem to be caused by inhibited signaling through NFKB, IRF-3, and IRF-8.

- Monocytes/macrophages. Low levels of valproic acid alter the differentiation of human monocyte-derived macrophages and their expressions of CXCL8/IL-8, IL-1 $\beta$, IL-6, TNF $\alpha$, and IL-10 (but not IL-12), whereas higher valproic acid levels reduce the release of cytokines in general [42]. Furthermore, valproic acid can enhance the expansion of nonclassical macrophages [43], with an overexpression of CD163 (but no effect on CD86 expression), decreased IL1- $\beta$ and TNF $\alpha$ expression, as well as increased expressions of anti-inflammatory IL-10 and TGF- $\beta 1$.

- Mesenchymal stem/stromal cells (MSCs). Valproic acid increases the glycolytic, respiratory, and T-cell suppressive capacity of MSCs [44]; increases their CXCR7 expression; increases the migratory capacity of bone marrow MSCs [45]; and induces osteogenic differentiation of human MSCs [33].

To conclude, valproic acid can modulate the function of several immunocompetent/immunomodulatory cells, but it is difficult to know whether this immunomodulation is important for direct (e.g., cytotoxic activity) or indirect (e.g., regulation of angiogenesis through cytokine or protease release) antileukemic effects of various immunocompetent cell subsets in vivo.

\subsection{Altered Systemic Mediator Levels and Metabolic Regulation during Treatment with Valproic} Acid in AML Patients

Valproic acid alters the serum levels of many different soluble mediators [46], including interleukins, chemokines, and growth factors for hematopoietic as well as endothelial cells. The levels of soluble HSPs, inducing HSP70 and HSP90 that may be associated with prognosis in human AML [46], as well as the levels of soluble endocan (i.e., a proteoglycan) are altered [35].

Valproic acid therapy alters the systemic serum metabolic profiles of AML patients [5]: it had minor effects on glucose metabolism but caused extensive alteration of lipid and amino acid metabolite levels. These effects on systemic levels of soluble mediators may influence immunocompetent cells and/or the functional status and therefore the chemosen- 
sitivity of AML cells through modulation of intracellular signaling (e.g., ligation of Toll-like receptors by metabolites or cytokines) or through altered epigenetic regulation by, for example, lipid/fatty acid metabolites [12,47-53].

\section{Experimental and Clinical Studies of ATRA in Non-APL Variants of AML \\ 3.1. Experimental and Clinical Studies of ATRA Effects on AML Cells}

The effects of ATRA and other vitamin A derivatives in non-APL AML have been reviewed in several recent excellent reviews [4,6,54-57], and for this reason, these effects are briefly described.

Experimental studies suggest that the antileukemic effect of ATRA varies between patients $[4,58]$, and this is further supported by clinical studies. A large phase III clinical trial including 242 elderly patients above 60 years of age described higher response rates and better event-free as well as overall survival in patients receiving ATRA together with conventional intensive induction and first consolidation chemotherapy [59]. A later reanalysis of this study suggested that the favorable effect was restricted to the subset of patients with NPM1 mutations with FLT3-wild type (wt) [60]. Another smaller study also including elderly patients described a similar improvement when patients received ATRA in addition to standard intensive chemotherapy, although this beneficial effect was observed only for patients with low levels of the transcriptional cofactor MN1 [61]. However, other studies have described no effect of ATRA when combined with conventional intensive chemotherapy, and this was true both for analyses of the overall patient populations as well as patient subset analyses [62,63]. Furthermore, a recent meta-analysis including eight previous studies also concluded that ATRA did not have any effect in non-APL variants of AML when combined with conventional intensive treatment [64]. It should be emphasized that these previous studies of ATRA differed with regard to several parameters, e.g., patient age, cytotoxic drug treatment, and treatment schedules. Finally, two recent studies suggested that ATRA may have an effect when combined with hypomethylating agents (see Section 2.2) $[19,65]$, and especially azacitidine seems to be effective at least in the treatment of AML relapse after allotransplantation (see Section 7.1).

Several studies suggest that the effects of ATRA on primary non-APL AML cells vary between patients. The following factors seem to be associated with susceptibility to ATRA:

- $\quad t(8 ; 21)$ AML. The RUNX1-RUNX1T1 translocation seems to confer ATRA resistance [66], although this has been questioned by another study [67].

- $\quad$ FLT3-ITD. Studies in an animal model of FLT3-ITD/NPM1c-driven AML suggest that ATRA has an antileukemic effect in this AML model through effects on leukemic stem cells, but this pharmacological effect is counteracted by experimental expression of the stem cell-associated transcription factor EVI1 [58].

- $\quad$ NPM1 mutations. Experimental studies suggest that ATRA can lead to degradation of mutated NPM1 with re-localization of NPM1-wt encoded by the second gene and therefore can induce cell cycle arrest, differentiation, and increased sensitivity to conventional cytotoxic drugs $[68,69]$. These observations are supported by certain clinical studies, as described above $[59,60]$.

- IDH1 mutations. Experimental studies suggest that patients with IDH1 mutations are more sensitive to ATRA [70].

- High MN1 expression. MN1 encodes a transcription cofactor that is a member of the RAR/RXR complex, and high expression is associated with resistance to ATRA [61].

- High EVI1 expression. This gene encodes a stem cell-associated transcription factor that is downregulated during hematopoietic differentiation. High expression is observed for $10 \%$ of AML patients and is associated with an adverse prognosis [58,71-73]. This factor is upregulated by ATRA [74-76], and high EVI1 levels seem to enhance the transcriptional response to ATRA [77], thereby causing differentiation induction, decreased clonogenic proliferation, and decreased AML engraftment in immunocompromised mice [78]. These antileukemic effects seem to be caused by the effects of ATRA on the AML stem cells for patients with stem cell-derived leukemia and 
therefore high EVI1 expression, but the effect is weak or absent in AML derived from progenitor cell transformation and shows low EVI1 expression [79]. However, this effect of EVF1 expression is probably more complex because it may be further modulated by other genetic abnormalities [58].

Additional pharmacological factors may also influence the effect of ATRA. First, bone marrow stromal cells can degrade ATRA and therefore limit the antileukemic effects [67]. Second, the aldehyde dehydrogenase (ALDH) enzymes are involved in the synthesis of retinoids and metabolism of reactive aldehydes [80,81]. ATRA can downregulate ALDH activity and therefore sensitize AML cells to cytotoxic drugs [80]. A recent proteomic study demonstrated increased ALDH activity especially in primary AML cells derived from elderly patients [82], an observation suggesting that the antileukemic effects of ATRA may also be associated with patient age. Taken together, these observations suggest that the antileukemic effects of ATRA differ between patients, and this may explain the discrepancies between clinical studies regarding the antileukemic effects of ATRA.

\subsection{Effects of ATRA on Normal Hematopoietic and Bone Marrow Stromal Cells}

ATRA has several effects on normal hematopoiesis and is important both for granulopoiesis and erythropoiesis. A detailed review of these effects is outside the scope of this article, but a detailed discussion with additional references can be found in recent reviews [83-85]. ATRA may also influence both normal and leukemic hematopoiesis indirectly through its effects on MSCs, osteoblasts, and endothelial cells in the bone marrow microenvironment [86-90].

\subsection{Effects of Vitamin A/ATRA on Normal Immunocompetent Cells}

The role of vitamin $\mathrm{A}$ in immunoregulation has been reviewed in several recent articles [85,91-95], and these effects are therefore only briefly summarized. Firstly, the importance of vitamin A and its derivatives for immunity is illustrated by vitamin A deficiency that leads to decreased humoral and cellular responses, inadequate immune regulation, weak responses to vaccines, and poor lymphoid organ development [92,94]. Vitamin A can alter the levels and/or the function of several T cell subsets, including both proinflammatory subsets as well as Treg cells [92-95]. With regard to ATRA, this agent can both facilitate the development of Treg cells [94-96] and enhance anticancer immune reactivity [97]. Second, retinoic acid can alter trafficking/homing of immunocompetent cells, including both $\mathrm{T}$ and B cells [93]. Third, retinoic acid/ATRA can modulate the function of other immunocompetent cells [92,93]. Vitamin A is an important regulator of several innate immune cells, e.g., causing altered function of monocytes/macrophages and Innate lymphoid cells together with reduced levels of myeloid-derived suppressor cells in patients receiving Car-T cell therapy $[92,93,98]$. The altered differentiation and trafficking of monocytes/macrophages by ATRA then results in increased differentiation towards the M2 phenotype with inhibition of macrophage-mediated immunity and favored development of tolerance $[87,88,94,99]$. Finally, the effect of retinoic acid on the balance between immunity versus tolerance is further modulated by the microenvironment. Thus, vitamin A and probably also ATRA have extensive effects on both the development and the function of several immunocompetent cell subsets, and the effect of ATRA treatment will probably be difficult to predict in AML patients both during conventional intensive chemotherapy and following allogeneic stem cell transplantation.

The conclusion from several previous reviews is that the effects of vitamin A on immunoregulation and immunocompetent cells will depend on the dose, the tissue, and the biological context of the immune response $[85,93,94]$. Retinoic acid seems to modulate Treg differentiation in steady state/homeostasis but promotes activation of proinflammatory cell subsets during ongoing immune responses $[85,93,94]$. Both auto- and allotransplant recipients will have a $\mathrm{T}$ cell defect lasting several months after the hematopoietic reconstitution with normalization of peripheral blood neutrophil, monocyte subset, and thrombocyte counts [100-102]. It is not known how ATRA/vitamin A deficiency will 
influence this developing posttransplant immune system. Furthermore, allotransplant recipients seem to have an altered vitamin A metabolism during the first 28 days posttransplant compared with the pretransplant vitamin A status; these alterations are probably due to conditioning/reconstitution/pancytopenia rather than the early posttransplant nutritional status [103]. Finally, local production of retinoids by immunocompetent cells (monocytes and dendritic cell) has important immunoregulatory functions, but it is not known how high systemic doses will influence local retinoid-induced immunoregulation in various microenvironments. These overall data further illustrate that the immunological effects of posttransplant ATRA therapy are very difficult to predict based on the currently available knowledge.

The effects of ATRA on immunocompetent cells will be of particular importance in allotransplant recipients because immune-mediated antileukemic activity contributes to the overall antileukemic effect of this strategy but especially because immune-mediated complications contribute to the posttransplant non-relapse mortality [104]. ATRA is important for trafficking of immunocompetent cells, including the homing of various immune cell subsets to the gut that is one of the organs commonly affected in both acute and chronic graft versus host disease (GVHD) $[105,106]$. The importance of vitamin A for immunoregulation in allotransplant recipients is suggested by several observations. First, studies in animal models have shown that vitamin A deficiency alters the phenotype of acute GVHD; posttransplant $\mathrm{T}$ cell homing to the gut is then reduced in vitamin A-deficient mice, but other organs show more serious affection [107]. Second, chronic vitamin A deficiency changes the composition of the $\mathrm{T}$ cell compartment of donor mice with a reduction in the percentage of $\mathrm{CD}^{+} \mathrm{T}$ cells, and a decreased proportion of donor $\mathrm{CD} 4^{+} \mathrm{T}$ cells in marrow grafts leads to reduced incidence and severity of GVHD [108]. This study also showed that treatment with a pan-RAR antagonist inhibited donor T cell RAR signaling, and reduced the $T$ cell alloreactivity and its ability to cause lethal GVHD. Third, in another animal study, exogenous RA significantly increased the expression of gut-homing molecules (CCR9 and $\alpha 4 \beta 7$ integrin) on donor $\mathrm{T}$ cells and augmented the accumulation of proinflammatory $\mathrm{CD}^{+}$and $\mathrm{CD}^{+} \mathrm{T}$ cells in the gut mucosa, leading to an exacerbation of colonic GVHD with increased mortality [109]. Retinoic acid depletion in the recipient mice then reduced the expression of gut-homing molecules in donor T cells after HSCT and attenuated the ability of these cells to cause lethal GVHD. Finally, the function of both host and donor dendritic cells was also influenced by the vitamin A status and this influences the risk of GVHD in this murine model [110].

The results from animal studies are in contrast with the observations from two studies in humans. A study of 114 consecutive pediatric allotransplant recipients demonstrated low levels of vitamin A at day +30 posttransplant to be associated with increased gastrointestinal GVHD at day $+100(38 \%$ vs. $12.4 \%, p=0.0008)$. The same was true for treatment-related mortality $(17.7 \%$ vs. $7.4 \%$ at 1 year, $p=0.03)$, and bloodstream infections were increased in patients with low vitamin A levels ( $24 \%$ vs. $8 \%$ at 1 year, $p=0.03$ ) [111]. Surprisingly, the expression of the gut homing receptor CCR9 on T-effector memory cells 30 days after transplant was increased in children with low vitamin A levels [111]. Another study suggested that low vitamin A levels are also associated with chronic GVHD [112].

Taken together, these observations suggest that ATRA therapy after allotransplantation influences the immunological functions of the stem cell recipients, but possible effects with regard to the development of GVHD are difficult to predict and further studies are needed.

\subsection{Altered Metabolic Regulation during Treatment with ATRA in AML Patients}

ATRA alters the systemic (i.e., serum) metabolic profiles in AML patients, especially the levels of several amino acid and lipid metabolites, but these effects are relatively weak compared with valproic acid [5]. ATRA has only minor effects on glucose metabolism [5]. 


\subsection{The Complexity of Combining Valproic Acid and ATRA in the Treatment of AML}

The results described previously in Sections 2 and 3 show that valproic acid and ATRA have complex effects, including direct effects on the AML cells as well as indirect effects mediated by their influence on neighboring cells in the bone marrow microenvironment, e.g., normal hematopoietic cells, bone marrow stromal cells that support both normal and leukemic hematopoiesis, and various immunocompetent cells. Figure 1 summarizes the effects of the two pharmacological agents on various cell types and therefore illustrates the complexity of combined valproic acid/ATRA therapy.

\section{MOLECULAR MECHANISM AND EFFECTS IN AML CELLS}

Valproic acid is a HDAC inhibitor; it increases acetylation of cytoplasmic and nuclear proteins and thereby has antiproliferative and proapoptotic effects in human AML cells.

ATRA is a high-affinity RAR $\alpha \beta \gamma$ ligand; binding to these nuclear receptors alters the transcription of a wide range of genes. It induces differentiation and apoptosis in primary human AML cells.

\begin{tabular}{|c|c|c|}
\hline Normal hematopoiesis & Marrow stromal cells & Immunocompetent cells \\
\hline $\begin{array}{l}\text { Valproic acid increases } \\
\text { stem cell proliferation. Cyto- } \\
\text { penia can be a toxic effect } \\
\text { on more mature progenitors. }\end{array}$ & $\begin{array}{l}\text { Valproic acid influences the } \\
\text { function or differentiation of } \\
\text { MSCs, osteoblasts and } \\
\text { endothelial cells. }\end{array}$ & $\begin{array}{l}\text { Valproic acid modulates the } \\
\text { function of } T \text { cells, dendritic } \\
\text { cells and monocytes- } \\
\text { macrophages. }\end{array}$ \\
\hline $\begin{array}{l}\text { ATRA supports normal } \\
\text { hematopoiesis, including } \\
\text { both granulopoiesis and } \\
\text { erythropoiesis. }\end{array}$ & $\begin{array}{l}\text { ATRA alters the function } \\
\text { and/or differentiation of } \\
\text { MSCs, osteoblasts and } \\
\text { endothelial cells. }\end{array}$ & $\begin{array}{l}\text { ATRA affects regulatory and } \\
\text { proinflammatory } \mathrm{T} \text { cells, } \\
\text { monocytes } \\
\text { macrophages. }\end{array}$ \\
\hline
\end{tabular}

Figure 1. A summary of important effects of valproic acid and ATRA on AML cells, normal hematopoiesis, bone marrow stromal cells, and immunocompetent cells. For a detailed and more complete description of the pharmacological effects including references, please see Sections 2 and 3.

3.6. Valproic Acid/ATRA Based Anti-AML Therapy: What Can We Learn from Proteomic and Phosphoproteomic Studies

A recent study investigated the in vivo effects of ATRA alone and ATRA/valproic acid-based therapy on the proteomic and phosphoproteomic profiles of primary human AML cells [32]. The results of these studies are summarized in Table 2 . This study suggests that the pretreatment proteomic and phosphoproteomic profiles of the AML cells show significant differences. Furthermore, the analyses during ATRA/valproic acid in vivo 
therapy showed that the in vivo concentrations of both these drugs reached levels that could influence important cellular processes in AML cells, especially processes involving RNA processing/metabolism/splicing. However, additional functions were also affected. These observations also reflect the complexity of these pharmacological effects.

Table 2. Proteomic studies of patients receiving anti-AML therapy based on ATRA plus valproic acid. Proteomic and phosphoproteomic comparisons of AML cells derived from responders and nonresponders and leukemic cells derived before and during ATRA/valproic acid therapy [32].

Pretreatment Differences between Responders and vs. Nonresponders

\begin{tabular}{|c|c|}
\hline Proteomic Effects & Phosphoproteomic Effects \\
\hline $\begin{array}{c}\text { Responders: High levels of proteins reflecting } \\
\text { neutrophil differentiation, intracellular transport, } \\
\text { p53 signaling, and amino acid metabolism } \\
\text { Nonresponders: high levels of proteins involved in } \\
\text { transcription, cytoplasmic organelles, and lipid metabolism }\end{array}$ & $\begin{array}{l}\text { Responders: High phosphorylation of proteins reflecting } \\
\text { cytoskeleton organization, cell cycle regulation, } \\
\text { membrane bound, and extracellular organelles } \\
\text { Nonresponders: high phosphorylation of proteins } \\
\text { involved in RNA binding/splicing }\end{array}$ \\
\hline \multicolumn{2}{|c|}{ in vivo effects of ATRA } \\
\hline $\begin{array}{l}\text { Responders: Altered ribonucleoprotein assembly, RNA } \\
\text { biosynthetic process, histone modification, chromatin } \\
\text { binding, kinase activity, and signal transduction } \\
\text { Nonresponders: altered extracellular secretion/organelles, } \\
\text { clathrin complex, cytoskeleton organization, } \\
\text { and RNA function/synthesis }\end{array}$ & $\begin{array}{l}\text { Responders: Altered RNA processing and splicing, } \\
\text { Rho GTPase binding, Rac GTPase binding, } \\
\text { transcription elongation, and ribosome } \\
\text { Nonresponders: RNA splicing and processing, } \\
\text { nuclear body, and plasma membrane }\end{array}$ \\
\hline \multicolumn{2}{|c|}{ Further modulation by adding valproic acid to ATRA in vivo } \\
\hline $\begin{array}{l}\text { Responders: Further modulation of mitochondrial function, } \\
\text { ribonucleoprotein assembly, and kinase activity } \\
\text { Nonresponders: RNA binding and splicing, } \\
\text { mRNA function, and clathrin complex }\end{array}$ & $\begin{array}{l}\text { Responders: Altered RNA processing, nuclear speck, } \\
\text { and actin filament binding; further modulation of } \\
\text { Rac GTPase binding and transcription elongation } \\
\text { Nonresponders: Altered cyclin-dependent protein } \\
\text { ser/thr kinase activity, and cellular catabolic process; } \\
\text { further modulation of RNA splicing/processing }\end{array}$ \\
\hline
\end{tabular}

Even though both ATRA and valproic acid have effects on transcriptional regulation and gene expression, we regard their effects on protein levels and posttranscriptional protein modulation (i.e., phosphorylation) to be of particular importance because several new AML therapies target various proteins (e.g., bcl2 inhibitors) or protein modifications (e.g., receptor tyrosine kinase inhibitors). In our opinion, proteomic/phosphoproteomic studies are therefore an important part of the scientific basis for the design of future pharmacological combinations.

\section{Clinical Studies of Valproic Acid and ATRA in AML}

Several studies have investigated the effects of valproic acid monotherapy or combination therapy including ATRA or low-dose chemotherapy for elderly or unfit AML patients, including patients with high-risk or relapsed AML [3,22,35,37,113-120]. Although many of these studies are relatively small, some general conclusions can be made:

- Only a minority of patients (approximately 25-35\%) respond to this treatment.

- Most responders show stabilized disease when using the MDS response criteria (see Section 6.2). Exceptional patients achieve complete hematological remission, but this is usually seen when valproic acid is combined with ATRA plus low-toxicity chemotherapy.

- The most common response is stabilized/increased peripheral blood platelet counts, and for most patients, the duration of such responses is 2-5 months, although exceptional patients without complete hematological remission have responses that last for 12-18 months. The improvement in platelet counts can be from pretreatment levels below $10 \times 10^{9} / \mathrm{L}$ to stabilization at or above $20-50 \times 10^{9} / \mathrm{L}$. 
- $\quad$ Responses can even be seen for patients with high-risk disease (e.g., relapsed AML) [22,37] and for patients with valproic acid serum levels below the therapeutic level.

- $\quad$ Toxic effects are usually dose-dependent and reversible, and the most common toxicities are gastrointestinal side effects and fatigue.

Thus, the valproic acid plus ATRA combination has clinically relevant antileukemic effects with acceptable toxicity in human AML, but the effect is usually limited unless low-toxicity chemotherapy is added.

\section{Panobinostat-An Alternative HDAC Inhibitor to Valproic Acid in AML Therapy}

Experimental studies suggest that the HDAC inhibitor panobinostat downregulates the expression of the transcription factor E2F1 and therefore suppresses the expressions of BRCA1, CHK1, and Rad51; this leads to an increased susceptibility to both cytarabine and daunorubicin-induced apoptosis [121]. Studies in AML cell lines suggest that panobinostat has largely overlapping and synergistic effects on gene expression profiles compared with DNA methyl transferase inhibitors [122]. Panobinostat has been tried in clinical studies in combination with standard AML induction therapy followed by panobinostat maintenance monotherapy [123]. The most frequent adverse events during monotherapy were thrombocytopenia and gastrointestinal side effects (nausea, vomiting, dyspepsia, and diarrhea), and similar side effects were observed when the drug was used after allogeneic stem cell transplantation for high-risk AML [124]. Two additional studies also suggest that panobinostat has moderate antileukemic activity, acceptable toxicity [125,126], and additional immunomodulatory effects with decreased number and activity of bone marrow infiltrating TNF receptor expressing Treg cells [127] but increased levels and function of other Treg cell subsets [128,129].

Only a few early clinical studies of panobinostat in AML have been published. First, it has been combined with intensive chemotherapy both for younger patients [125] and elderly patients receiving conventional intensive therapy $[123,130]$. It has also been combined with hypomethylating agents, including both decitabine [131], and azacitidine [132]. Third, it has been used as a maintenance treatment after intensive chemotherapy and could then reduce the effects of minimal residual disease for a subset of patients [123]. Finally, it has also been used as an additional posttransplant antileukemic treatment for patients receiving allogeneic stem cell transplantation for high-risk AML/MDS [124]. Taken together, these studies suggest that the addition of panobinostat can increase the toxicity, but the toxicity is still acceptable and this seems to be true also for allotransplant recipients.

\section{The Treatment of Post-Allotransplant AML Relapse with ATRA, Valproic Acid, Hydroxyurea, and Azacitidine Illustrated by Four Case Reports \\ 6.1. A Treatment Protocol for the Use of Valproic Acid and ATRA in Low-Toxicity Combination Therapy}

To the best of our knowledge, there are no reports on the use of valproic acid + ATRA + azacitidine in allotransplant recipients. We therefore established a protocol where AML patients were included after written informed consent; the study was performed in accordance with the Helsinki declaration and approved by the regional ethics committee (REK Vest 2011/1257, REK 2011/1241) and The Norwegian Medicines Agency (Legemiddelverket; Ref. 11/09187-2 and code 343). Collection of the clinical data was registered by official Norwegian authorities (Personvernombudet, Haukeland University Hospital, registered 29092011), and the study was registered in public databases (ClinicalTrials.gov no. NCT01369368 and EudraCT no. 2011-002689-19). All patients had non-APL variants of AML diagnosed in accordance with the WHO criteria [133]. The diagnosis of AML relapse was based on the ELN criteria similar to previous studies [134]. 
This phase II study intended to include at least 10 patients. The scientific basis for the design of the study is described in Table 3. Our study included low-dose azacitidine and was stopped after a large retrospective study reported that monotherapy with higher azacitidine doses was effective and had acceptable toxicity when treating post-allotransplant AML relapse [135]. Our hypothesis was that sequential azacitidine/hydroxyurea combined with valproic acid + ATRA would be feasible as an outpatient treatment for unfit AML patients with leukemia relapse after allotransplantation. The treatment was given as five-week cycles until disease progression. First, valproic acid was started on day 1 and continued throughout the cycle; it was administered as an initial intravenous bolus dose of $5 \mathrm{mg} / \mathrm{kg}$ body weight and thereafter as an intravenous infusion for $24 \mathrm{~h}$ until oral treatment started; and the oral dose was increased until the therapeutic serum level or the maximal tolerated dose was reached. Second, oral ATRA $22.5 \mathrm{mg} / \mathrm{m}^{2}$ twice daily was given for the first 14 days of each cycle (day 1-14); this therapeutic strategy has previously been used for AML-stabilizing treatment $[22,35,37,136]$. Third, 5-azacitidine was administered as a subcutaneous injection at a fixed dose $100 \mathrm{mg}$ per day on days 1-3 of each cycle [137]. Finally, hydroxyurea was administered from day 15 to day 35 of the first cycle; for later cycles, it was administered from day 5 to day 35. The hydroxyurea dose in the first cycle was $500 \mathrm{mg}$ daily until day 21 and was thereafter increased to $1000 \mathrm{mg}$ daily when no signs of response were observed $[3,35,37,138]$. Donor lymphocyte infusions were allowed but were not given to any patient.

Table 3. A summary of the scientific basis for the design of the present protocol for treatment of posttransplant AML relapse based on ATRA plus valproic acid.

\section{Valproic acid [35,37,114,115]}

Treatment started on day 1 of the first cycle and continued until disease progression.

Early start of valproic acid therapy was regarded as important because it will often take 2-3 weeks before a response can be detected. First administered as intravenous infusion to reach a relevant therapeutic level as early as possible.

The dose was increased until one reached the highest level with acceptable toxicity or the recommended therapeutic serum level. Previous studies suggest that systemic levels lower than the therapeutic serum level can be effective.

\section{ATRA $[35,37]$}

Administered for days 1-14 of each five-week cycle.

The daily dose was $22.5 \mathrm{mg} / \mathrm{m}^{2}$ twice daily; this is similar to the dose used in APL.

A fourteen day duration has been used in previous AML studies of ATRA/valproic acid therapy. ATRA syndrome has not been observed with this dose and duration of treatment.

\section{Azacitidine [137]}

Included patients were regarded as unfit for more intensive treatment.

The risk of severe toxicity was reduced using a fixed dose of $100 \mathrm{mg}$ daily for the first three days of each cycle.

The three-day low-toxicity regimen has a clinically relevant antileukemic effect in posttransplant AML relapse and can be effective even in patients with high-risk karyotypes.

The interval (i.e., duration of each cycle) was increased to five weeks to further reduce the risk of severe toxicity.

Azacitidine started early from day 1 because it may last several weeks before a response is seen (see Section 7.1).

Hydroxyurea $[35,37,138]$

The use of hydroxyurea in addition to ATRA/valproic acid was allowed in previous studies.

It started on day 15 of the first cycle to reduce the risk of initial severe toxicity.

In later cycles, it was administered at days 5-35 to avoid overlap with the azacitidine.

To reduce the risk of severe hematological toxicity, hydroxyurea dosing was guided by

normal peripheral blood cell counts and the level of circulating AML blasts in peripheral blood.

If this leukocytosis could not be controlled (defined as $>50 \times 10^{9} / \mathrm{L}$ ), we changed it to oral merkaptopurin or subcutaneous cytarabine, and we then used the same guideline as for hydroxyurea for dosing of these two drugs [138].

\subsection{What Should the Response Criteria Be for Patients Receiving AML Stabilizing Treatment?}

There are no generally accepted response criteria for patients receiving AML-stabilizing treatment. In our opinion, one should use the generally accepted criteria for complete hematological remission, i.e., $<5 \%$ blasts in the bone marrow together with normalization 
of peripheral blood cell counts [134]. In previous studies, we used peripheral blood cell counts to define disease stabilization $[5,35,37]$. First, stabilized platelet counts were defined as (i) an increase from lower platelet counts to stable values exceeding 15 or, (ii) for higher pretreatment levels, it was defined as an increase corresponding to a difference of at least $20 \times 10^{9} / \mathrm{L}$ from the nadir level, with this difference being $>20 \%$ of the nadir value. Second, increased neutrophil counts were defined as (i) an increase from $<0.5$ to $>1.0 \times 10^{9} / \mathrm{L}$ or, (ii) in the case of a higher pretreatment level, at least a doubling of the original value. Finally, increased reticulocytes were defined as (i) a doubling of the count or normalization of initially decreased levels. These effects had to be detected in at least two independent samples, and the duration of stabilization was defined as the time from first significantly altered levels until the first cell count below the pretreatment level.

\subsection{Case Reports}

Several studies have investigated the combination of hypomethylating agents and valproic acid in AML $[19,113,138-142]$. Most studies included elderly and unfit patients, and the most common valproic acid toxicities were encephalopathy and gastrointestinal side effects that seemed to be dose-dependent and reversible. However, many of these patients developed such side effects even at relatively low valproic acid serum levels. Only one of the studies observed an association between effect of treatment and high valproic acid serum levels [113], but response to valproic acid + ATRA treatment has been observed also for patients with serum levels below the therapeutic level (see Section 4). Important patient characteristics are summarized in Table 4.

\subsubsection{Case Report 1}

The patient was a 22-year-old male with an early second AML relapse (complex karyotype) four months after re-transplantation for the first posttransplant relapse (Table 4). His ECOG performance status was 0 when he started antileukemic treatment according to the study protocol. He then had clinical signs of GVHD (skin and gastrointestinal tract); these symptoms increased when immunosuppression was reduced, and he therefore continued taking cyclosporine (target level 100-200 $\mu \mathrm{g} / \mathrm{L}$ ) and prednisolone at $12.5 \mathrm{mg}$ daily. The ECOG status was 0 with minimal GVHD symptoms until the end of the third cycle. During the first cycle, he remained neutropenic and required erythrocyte transfusions, and his platelet count decreased to $21 \times 10^{9} / \mathrm{L}$. His platelet counts later increased to stable levels above $40-50 \times 10^{9} / \mathrm{L}$ (maximal level $101 \times 10^{9} / \mathrm{L}$ ) and his peripheral blood blast counts were stable, but he still required regular erythrocyte transfusions. The median valproic acid serum level was $395 \mu \mathrm{mol} / \mathrm{L}$ (range 299-512 $\mu \mathrm{mol} / \mathrm{L}$ ) until he was admitted to a hospital by the end of the third cycle when he had signs of AML progression with musculoskeletal pains, increasing peripheral blood blast counts and severe thrombocytopenia. Progression occurred after 94 days of treatment, and he died 29 days later.

\subsubsection{Case Report 2}

The patient was a 57-year-old female who was allotransplanted for AML in second complete remission with a matched unrelated donor. She developed acute GVHD in the skin early after transplantation but required only topical steroid treatment. AML relapse was diagnosed 71 days after transplantation (Table 4). Cyclosporine treatment was stopped, and she started antileukemic therapy according to the protocol. However, she developed increasing diarrhea during the first three weeks after inclusion and could no longer receive enteral nutrition or medication. Acute GVHD was suspected, and she started treatment with cyclosporine combined with systemic (prednisolone $30 \mathrm{mg} /$ day) and topical oral steroids. However, her gastrointestinal symptoms continued and her ECOG status increased to 3-4. She died with a clinical picture of AML progression, severe acute GVHD, and pneumonia on day +100 posttransplant after 24 days of treatment for the relapse. 
Table 4. Important characteristics for patients receiving stabilizing treatment for relapse AML after allotransplantation; the status at inclusion in the study.

\begin{tabular}{|c|c|c|c|c|}
\hline & CASE 1 & CASE 2 & CASE 3 & CASE 4 \\
\hline Age/gender & 22 years /male & 57 years $/$ female & 63 years $/$ male & 55 years, female \\
\hline Status at inclusion & $\begin{array}{l}\text { Second relapse } 122 \text { days } \\
\text { after second allo-SCT }\end{array}$ & Second relapse 71 days after allo-SCT & First relapse 113 days after allo-SCT & $\begin{array}{l}\text { AML relapse } 20 \text { months } \\
\text { after allo-SCT for aCML }\end{array}$ \\
\hline Status at allo-SCT & Second remission & Second remission & First remission & Remission \\
\hline Stem cell donor & HLA identical sibling donor & MUD & HLA identical sibling & HLA identical sibling \\
\hline Conditioning & Myeloablative & Myeloablative & Reduced intensity & Reduced intensity \\
\hline Acute GVHD & Skin, GI-tract & Skin, GI tract & Skin, GI tract & No \\
\hline ECOG status & 0 & 2 & 0 & 0 \\
\hline \multicolumn{5}{|c|}{ Pretreatment peripheral blood cells/transfusions } \\
\hline Hemoglobin & $12.0 \mathrm{~g} / 100 \mathrm{~mL}$ & $10.5 \mathrm{~g} / 100 \mathrm{~mL}$ & $10.2 \mathrm{~g} / 100 \mathrm{~mL}$ & $10.1 \mathrm{~g} / 100 \mathrm{~mL}$ \\
\hline Neutrophils $\left(\times 10^{9} / \mathrm{L}\right)$ & $2.4 \times 10^{9} / \mathrm{L}$ & $4.5 \times 10^{9} / \mathrm{L}$ & $1.0 \times 10^{9} / \mathrm{L}$ & $0.5 \times 10^{9} / \mathrm{L}$ \\
\hline Platelets $\left(\times 10^{9} / \mathrm{L}\right)$ & $88($ decreasing to 21$) \times 10^{9} / \mathrm{L}$ & $13 \times 10^{9} / \mathrm{L}$ & $6 \times 10^{9} / \mathrm{L}$ & $12 \times 10^{9} / \mathrm{L}$ \\
\hline AML blasts $\left(\times 10^{9} / \mathrm{L}\right)$ & $2.5 \times 10^{9} / \mathrm{L}$ & $1.5 \times 10^{9} / \mathrm{L}$ & $<1 \%$ of leukocytes & $<0.2 \times 10^{9} / \mathrm{L}$ \\
\hline Valproic acid levels during first cycle & & $\begin{array}{c}253 \mu \mathrm{mol} / \mathrm{L} \text { after iv and } 40-50 \mu \mathrm{mol} / \mathrm{L} \\
\text { after oral administration }\end{array}$ & $\begin{array}{c}\text { Exceeding } 400 \mu \mathrm{mol} / \mathrm{L} \text { after iv but } \\
<100 \mu \mathrm{mol} / \mathrm{L} \text { after oral administration }\end{array}$ & \\
\hline Red cell/platelet transfusions first cycle & $2 / 0$ & Cycle 1 not completed & Cycle 1 not completed & \\
\hline \multicolumn{5}{|l|}{ Survival } \\
\hline From (last) allo-SCT & 240 days & 100 days & 132 days & 23 months \\
\hline From relapse & 133 days & 29 days & 62 days & 110 days \\
\hline From start of therapy & 128 days & 24 days & 46 days & 128 days \\
\hline From progression & 29 days & No response & No response & 30 days \\
\hline
\end{tabular}

Abbreviations: aCML, atypical chronic myeloid leukemia, GI, gastrointestinal; iv, intravenous; LDH, lactate dehydrogenase; MUD, matched unrelated donor; SCT, stem cell transplantation. 


\subsubsection{Case Report 3}

The patient was a 63-year-old male who developed secondary AML after treatment for non-Hodgkin's lymphoma. He achieved complete hematological remission after the second induction cycle and was transplanted with reduced intensity conditioning (RIC). AML relapse was diagnosed less than four months posttransplant. Skin GVHD was diagnosed before the relapse and was treated with oral prednisone $30 \mathrm{mg}$ daily in addition to topical steroids and continued cyclosporine therapy. Cyclosporine treatment was stopped when relapse was diagnosed, whereas steroid use was gradually reduced. The patient developed severe diarrhea three weeks after the start of the study treatment. Despite increased steroid treatment, the symptoms did not improve; he could not receive oral nutrition/medication and was removed from the study 46 days after inclusion. He died 21 days later due to AML progression, severe gastrointestinal GVHD, and pneumonia.

\subsubsection{Case Report 4}

A 39-year-old female was diagnosed with atypical chronic myeloid leukemia (aCML). She received RIC conditioning and was transplanted from a HLA identical sibling. There was no acute GVHD, but she relapsed 20 months posttransplant with AML. At the start of treatment, she had 30\% leukemic blasts in the bone marrow. She received azacitidine and hydroxyurea according to the protocol together with valproic acid (median serum level $432 \mu \mathrm{mol} / \mathrm{L}$, range $334-496 \mu \mathrm{mol} / \mathrm{L}$ during the treatment period). Pretransplant peripheral blood cell counts showed total leukocytes $6.8 \times 10^{9} / \mathrm{L}$ with mainly blast cells and severe thrombocytopenia $<10 \times 10^{9} / \mathrm{L}$. Her platelets increased to 12 during the first cycle; at the same time, her leukocytes were $22.6 \times 10^{9} / \mathrm{L}$ with neutrophils $5.9 \times 10^{9} / \mathrm{L}$. After the second azacitidine treatment, the dose of hydroxyurea was gradually increased to $1500 \mathrm{mg}$ daily. The situation was stable with no signs of GVHD, total leukocytes in the range of $20-30 \times 10^{9} / \mathrm{L}$, normalized neutrophils $5.9 \times 10^{9} / \mathrm{L}$, but platelets $<10 \times 10^{9} / \mathrm{L}$. She required erythrocyte transfusions every $2-3$ weeks from inclusion until disease progression was diagnosed 98 days after start of the treatment. She died 30 days later.

\subsubsection{Comments to the Case Reports}

All of our patients received a combination of sequential azacitidine/hydroxyurea, continuous valproic acid, and intermittent ATRA therapy. We emphasize that one should be very careful when making conclusions based on our case reports, but some suggestions can be made. First, especially case report 1 but also case report 4 suggest that our low-toxicity treatment stabilized the clinical status and could be administered while the patient was at home. Second, an acceptable quality of life with this outpatient treatment was then possible. Finally, the treatment probably did not induce GVHD, and this is in accordance with the previous studies of valproic acid effects on immunocompetent cells where immunosuppressive effects seem to dominate (see above). It is also in accordance with a previous pediatric study describing higher frequency of acute GVHD in patients with low vitamin A levels compared with higher levels [109]. However, for two of the patients with GVHD diagnosed before inclusion, a progression was seen after the start of treatment. We cannot exclude the possibility that ATRA and/or valproic acid contributed to this, although in our opinion, the reduction/end of ongoing immunosuppressive therapy when relapse was diagnosed was possibly more important. We also mention that a patient included in a previous study received valproic acid + ATRA + cytarabine and but did not develop GVHD either [138]. However, this question of GVHD development/progression has to be carefully addressed if valproic acid is further investigated in future clinical studies of posttransplant AML relapse.

To the best of our knowledge, no other data are available for such a combination treatment for posttransplant AML relapse, but a clinical study of low-dose treatment with the hypomethylating agent decitabine in combination with the alternative HDAC inhibitor panobinostat alone was recently published [131]. This treatment was used to intensify the 
antileukemic effects in patients without relapse, and these authors also concluded that the treatment was feasible with acceptable toxicity.

\section{The Current Treatment for AML Relapse after Allogeneic Stem Cell Transplantation}

Various strategies for posttransplant prophylaxis and treatment of AML relapse are summarized in Table $5[2,143]$, and some of the most common strategies are described more in detail below. Less intensive/toxic strategies will often be tried in maintenance and pre-emptive therapy, whereas more intensive treatment can be used if the intention is remission induction followed by re-transplantation. Combined treatment can be used, for example, to stop GVHD prophylaxis combined with azacitidine and possibly donor lymphocyte infusion if the patient has no signs of GVHD $[2,143,144]$.

Table 5. Prophylaxis and treatment of post-allotransplant AML relapse. The table presents the definition of relapse, the importance of the clinical status at the time of intervention, and the various pharmacological and immunological strategies for prophylaxis and treatment $[2,134,143,144]$.

Morphological definition of AML relapse

At least $5 \%$ myeloblasts in the bone marrow in a patient with previous diagnosis of AML;

if less than $10 \%$ of blasts, the increased blast count should be verified in a second bone marrow sample.

Therapeutic strategy depending on the status at the time of intervention

Maintenance therapy: No evidence for residual disease, i.e., molecular remission.

Pre-emptive therapy: Detection of posttransplant minimal residual disease.

Salvage therapy: Morphological signs of relapse.

\section{Pharmacological strategies}

Intensive chemotherapy, e.g., conventional induction chemotherapy that results

in complete remission usually of short duration for $25-30 \%$ of patients.

Low-toxicity chemotherapy, e.g., hypomethylating agents that results in 15-20\% complete remissions.

Targeted therapy: The pharmacological agent depends on the AML-associated genetic abnormalities,

e.g., IDH1/IDH2 inhibitors when IDH mutations and Flt3 inhibitors in patients with Flt3-ITD.

The bcl2-inhibitor venetoclax is now investigated in clinical trials.

The HDAC inhibitor panobinostat is in clinical trials.

\section{Antileukemic immunomodulation}

Early reduction of GVHD prophylaxis

Donor lymphocytes infusion

Re-transplantation after remission induction

\subsection{The Hypomethylating Agents Azacitidine and Decitabine}

As emphasized in a recent review [144], most clinical studies of hypomethylating agents in AML relapse after allotransplantation are relatively small and retrospective. The largest studies are summarized in Table 6 [135,137,144-152]. First, a response to this treatment is seen for a relatively large subset of patients, but these responses are usually of short duration and complete remissions are seen only for a relatively small fraction of patients. The maximal response can be reached as late as 100-150 days after the start of treatment, and remissions lasting for years have been observed for exceptional patients. Second, the most common and severe side effects are hematological toxicity, including neutropenic infections, but except for this, the treatment seems to be well tolerated. Third, the treatment has usually been combined with donor lymphocyte infusions (DLI), a treatment associated with a risk acute and chronic GVHD. Finally, azacitidine has been used in most studies, but decitabine is also effective and may induce responses even for patients who have failed on azacitidine. The doses differ between studies, and even relatively low doses of azacitidine can be effective (i.e., $100 \mathrm{mg}$ fixed dose daily for three days). Thus, the use of hypomethylating agents and especially azacitidine should be regarded as a well-documented therapeutic 
alternative for patients with AML relapse after allogeneic stem cell transplantation. The possibility of combination therapy should also be further considered, as illustrated by a recent study combining lenalidomide with azacitidine [152].

Table 6. Important studies investigating hypomethylating agents for treatment of relapsed AML after allotransplantation.

\begin{tabular}{|c|c|c|c|}
\hline Study & Treatment & Effect & Toxicity and GVHD \\
\hline $\begin{array}{l}\text { Lübbert et al. [137]. } \\
\text { Retrospective }(n=26) \text {. } \\
\text { Time from transplant to } \\
\text { relapse median } 248 \text { days } \\
\text { (55-1412 days). }\end{array}$ & $\begin{array}{l}\text { Azacitidine } 100 \text { mg total daily } \\
\text { dose, days } 1-3 \text { with } 21 \text { days } \\
\text { intervals, could be followed } \\
\text { by DLI was allowed. } \\
\text { Median number of } \\
\text { cycles } 2 \text { (range } 1-10 \text { ). }\end{array}$ & $\begin{array}{l}\text { Complete remission in } \\
4 \text { patients with duration } \\
450-820 \text { days. } \\
50 \% \text { with temporary } \\
\text { disease control. } \\
\text { Median survival } 136 \text { days }\end{array}$ & $\begin{array}{l}\text { Neutropenic infections } \\
\text { in } 4 \text { patients. } \\
\text { Acute GVHD } 2 \text { patients. }\end{array}$ \\
\hline $\begin{array}{l}\text { Czibere et al. [145]. } \\
\text { Retrospective }(n=22) \text {. } \\
\text { Time from transplant to } \\
\text { relapse I } 03 \text { days } \\
\text { (53-708 days). }\end{array}$ & $\begin{array}{l}\text { Azacitidine } 100 \mathrm{mg} / \mathrm{m}^{2} \text { daily } \\
\text { days } 1-5,2-5 \text { weeks interval, } \\
\text { DLI was allowed. } \\
\text { Median number of } \\
\text { cycles } 2 \text { (range } 1-8 \text { ). }\end{array}$ & $\begin{array}{c}\text { Response to azacitidine: } \\
16 \text { patients. } \\
\text { Median time to relapse } \\
433 \text { days (range } 114-769 \text { days); } \\
\text { median survival } 144 \text { days. }\end{array}$ & $\begin{array}{l}\text { Acute GVHD in } 6 \text { patients. } \\
\text { Hematological toxicity grade } \\
4 \text { in } 7 \text { patient; neutropenic } \\
\text { infections in } 6 \text { patients. }\end{array}$ \\
\hline $\begin{array}{l}\text { Steinmann et al. [146]. } \\
\text { Retrospective }(n=72) \text {. } \\
\text { Time from allograft to relapse } \\
253 \text { days (50-2126 days). }\end{array}$ & $\begin{array}{c}\text { Azacitidine } 100 \mathrm{mg} \text { daily for } \\
3 \text { days (5 days in first cycle if } \\
\text { leukocytosis) and repeated } \\
\text { every } 3 \text { weeks. } \\
\text { Median number of cycles } 2.7 \\
65 \text { patients received DLI }\end{array}$ & $\begin{array}{c}\text { Complete remission } 9.7 \% \text { (for } \\
\text { two patients lasting }>5 \text { years), } \\
\text { temporary disease } \\
\text { control } 44 \% \text {. } \\
\text { Median survival } 108 \text { days; } \\
\text { peripheral blood blasts }<1 \% \\
\text { predicted longer survival. }\end{array}$ & $\begin{array}{l}10 \text { patients developed acute } \\
\text { GVHD; } 9 \text { patients with } \\
\text { chronic GVHD. } \\
2 \text { patients with } \\
\text { therapy-related sepsis. } \\
\text { 28/72 hospitalized due to } \\
\text { infections; } 15 \text { patients with } \\
\text { grade } 3 / 4 \text { neutropenia. }\end{array}$ \\
\hline $\begin{array}{l}\text { Tessoulin et al. [147]. } \\
\text { Retrospective ( } n=31 \text { ). } \\
\text { Time from transplant to } \\
\text { relapse median } 3.7 \text { months } \\
\text { (range 1.7-37.6 months). }\end{array}$ & $\begin{array}{c}\text { Azacitidine } 75 \mathrm{mg} / \mathrm{m}^{2} \text { daily } \\
\text { for } 7 \text { days every } 4 \text { weeks. } \\
\text { DLI was allowed. } \\
\text { Median number of } \\
\text { cycles } 3 \text { (range } 1-12 \text { ). }\end{array}$ & $\begin{array}{l}4 \text { complete remissions. } \\
\text { 11/31 patients responded } \\
\text { to the treatment. } \\
\text { Median overall } \\
\text { survival } 153 \text { days. }\end{array}$ & $\begin{array}{l}\text { Grade } 3 / 4 \text { toxicities in } \\
36 \% \text { of patients. } \\
38 \% \text { readmitted to hospital, } \\
\text { the most common reasons } \\
\text { being fever, infection, } \\
\text { or neutropenia. }\end{array}$ \\
\hline
\end{tabular}

Schroeder et al. [148].

Retrospective $(n=154)$.

Time from transplant to relapse median 185 days (19-3349 days).
Azacitidine $50-100 \mathrm{mg} / \mathrm{m}^{2}$ for 5-7 days every 4 weeks. DLI allowed.

Median number of cycles 4 (4-14).
Complete remission 27\%; overall response rate $33 \%$.

Better overall survival for patients with MDS or $<13 \%$ bone marrow blasts; 2-years survival $29 \%$.
Acute GVHD 23\%. Chronic GVHD 27\%.

$29.3 \%$ with complete or partial remission. Higher response rates for patients transplanted in remission and for MDS. Longer survival for patients with low blast counts $(<20 \%)$ or $>6$ month from transplant to relapse.

Azacitidine $75 \mathrm{mg} / \mathrm{m}^{2}$ for 5-7 days every 4 weeks; DLI was allowed.

Median duration of treatment 53 days (range 2-1196 days).

(1-71 months).

Azacitidine $75 \mathrm{mg} / \mathrm{m}^{2}$ daily for 7 days every 4 weeks ( $\geq 6$ cycles; DLI allowed). Median bone marrow blasts $1.4 \%$.
3 patients with complete remission; 9 patients with partial remission.

3 additional patients with stabilization.

2-years overall survival 25\%.
Acute GVHD 29 patients, 4 with grade III. persisting disease (flow cytometry, karyotyping) before day +100 . 
Table 6. Cont.

\begin{tabular}{|c|c|c|c|}
\hline Study & Treatment & Effect & Toxicity and GVHD \\
\hline $\begin{array}{l}\text { Sommer et al. [150]. } \\
\text { Retrospective }(n=26) \text {. } \\
\text { Time from transplant to } \\
\text { relapse median } 306 \text { days } \\
\quad(76-4943) .\end{array}$ & $\begin{array}{l}\text { Decitabine } 20 \mathrm{mg} / \mathrm{m}^{2} \text { daily } \\
\text { for } 5 \text { or } 10 \text { days every } 4 \text { weeks; } \\
\text { one DLI during each cycle } \\
\text { was allowed. } \\
\text { Median number of } \\
\text { cycles } 2 \text { (range } 1-13 \text { ). }\end{array}$ & $\begin{array}{c}\text { Complete remission } 4 / 26 \text {, } \\
\text { partial remission } 1 / 26 . \\
\text { Median overall survival } \\
4.7 \text { months. }\end{array}$ & $\begin{array}{l}\text { Acute GVHD 17\%. } \\
\text { Chronic GVHD 6\%. }\end{array}$ \\
\hline $\begin{array}{l}\text { Schroeder et al. [151]. } \\
\text { Retrospective }(n=36) \text {. } \\
\text { Median time to relapse } \\
370 \text { days (43 2623). }\end{array}$ & $\begin{array}{c}\text { Decitabine } 20 \mathrm{mg} / \mathrm{m}^{2} \text { daily } \\
\text { for } 5 \text { or } 10 \text { days with } 4 \text { weeks } \\
\text { interval.; DLI was allowed } \\
\text { Median number of } \\
\text { cycles } 2 \text { (range } 111 \text { ). }\end{array}$ & $\begin{array}{l}\text { Overall response rate } 25 \% \\
\text { including } 6 \text { patients with } \\
\text { complete remission. } \\
\text { Two patients who failed } \\
\text { azacitidine reached } \\
\text { complete remission. }\end{array}$ & $\begin{array}{l}\text { Acute GVHD in } 7 \text { patients; for } \\
2 \text { of them no previous DLI. } \\
2 \text { patients with symptoms of } \\
\text { chronic GVHD. after DLI. }\end{array}$ \\
\hline $\begin{array}{l}\text { Craddock et al. [152]. } \\
\text { Prospective }(n=29) . \\
\text { Median time to relapse } \\
10 \text { months (1-39 months). }\end{array}$ & $\begin{array}{c}\text { Azacitidine } 75 \mathrm{mg} / \mathrm{m}^{2} \text { days } \\
\text { 1-7 followed by lenalidomide } \\
\text { ( } 25 \mathrm{mg} \text { daily determined as } \\
\text { the maximal tolerated dose }) \\
\text { days } 10-30 . \\
\text { Median number of } \\
\text { cycles } 3(0-11) .\end{array}$ & $\begin{array}{c}\text { Among } 15 \text { patients receiving } \\
\text { at least } 3 \text { cycles, there were } 3 \\
\text { complete remissions, } 3 \text { with } \\
\text { complete remission without } \\
\text { complete regeneration, and } \\
1 \text { partial remission. } \\
\text { Median overall survival was } \\
27 \text { months for responders and } \\
10 \text { months for nonresponders. }\end{array}$ & $\begin{array}{l}3 \text { patients developed acute } \\
\text { GVHD grade } 2-4 . \\
\text { Febrile neutropenia observed } \\
\text { in } 10 \text { patients; documented } \\
\text { infections in } 3 \text { patients and } \\
\text { sepsis in } 7 \text { patients. }\end{array}$ \\
\hline
\end{tabular}

\subsection{Posttransplant Immunomodulation}

The initial immunomodulatory strategy is to enhance the graft-versus-leukemia effect by reducing or ending immunosuppressive treatment. If significant GVHD or GVL effects do not occur after this intervention, DLI may be used to trigger GVL [144]. Several studies have used DLI in combination with azacitidine/decitabine (Table 6), and the risk of severe GVHD following this pharmaco-immunological intervention seems to be acceptable as long as DLI is not given too early posttransplant.

\subsection{Intensive Induction Chemotherapy and Retransplantation}

Intensive chemotherapy can be considered as a possible strategy especially for young patients that are fit enough to tolerate such treatments; if patients achieve complete remission, an allogeneic re-transplantation may be considered, but this decision should be individualized and should be based on careful evaluation of the risks of severe toxicity versus the possibility of maintained remission and cure [2,143]. This recommendation has also been given by other authors; patients with chemo-sensitive disease (i.e., achieving remission after initial chemotherapy) and having remission durations of at least 6-12 months after the first transplantation seem to be those who benefit the most, with long-term disease control after a second transplant $[2,135,143,153]$.

\section{Quality of Life for AML Patients}

\subsection{Quality of Life for AML Patients Receiving Intensive and Leukemia-Stabilizing Therapy}

Patients receiving the best supportive care alone for AML spend 25-30\% of their time in hospital and approximately $15 \%$ of their time attending clinic appointments [154]. Many of them have a high symptom burden [155], and one third of them are admitted to intensive care units during their initial symptoms [156]. Similar observations were also made in a third study; a significant proportion of elderly/unfit patients spend a significant part of their last days of life in hospital [157]. Thus, for patients without the possibility of being cured, the risk of additional toxicity causing a negative impact on the patients' quality of 
life (QoL) by AML-directed chemotherapy may outweigh the possible advantage of an antileukemic effect.

Two studies suggest that elderly/unfit AML patients treated with hypomethylating agents show improved QoL compared with patients receiving only supportive care $[158,159]$, but a major problem with one of these studies was a high rate of missing data [160]. The other study suggested that improvement in QoL was associated with response to treatment and delayed progression of the disease [159]. Studies of AML patients receiving more intensive treatment suggest that $\mathrm{QoL}$ declines during intensive treatment and thereafter recovers over time for patients achieving complete remission [160-162], but the impaired QoL may persist also after the end of the intensive treatment [163]. Allotransplant recipients who do not receive intensive treatment of their relapse will often have a shortened expected life time and a long-term reduction in their QoL due to the previous transplantation [164]; for such patients, it will be important to individualize the therapy and to carefully consider the treatment intensity and therefore the risk of toxicity from antileukemic therapy.

\subsection{Quality of Life after Allogeneic Stem Cell Transplantation}

Relatively few studies of health-related QoL are available for allotransplanted patients. One study investigated 115 patients during the first year posttransplant [165]; 72\% of these patients had AML and more than $90 \%$ of them received peripheral blood stem cell grafts. The cohort included 51 patients receiving myeloablative conditioning (median age 41 years, range 21-60 years) and 64 patients receiving RIC conditioning (median age 59 years, range 43-69 years). The progression-free survival after 1 year ( 59 vs. 53\%), overall survival, cumulative incidence of acute and chronic GVHD, relapse rate, and nonrelapse mortality did not differ between these two patient subsets. Both groups seemed to have a similar reduction in QoL when examined on day +30 posttransplant, and this was true both for the global QoL score as well as physical, role, social, cognitive, and emotional functioning. There was a slow recovery back to baseline QoL pretransplant levels during the first year posttransplant without any differences between the two groups. Furthermore, QoL one year posttransplant was also investigated in the MRC-AML10 study [166]. In this study, allotransplantation seemed to have an adverse impact on most QoL parameters compared with intensive consolidation chemotherapy or autotransplantation. Finally, another larger study also reported reduced QoL for allotransplant recipients compared with patients who received intensive chemotherapy, and this was especially true for patients receiving continued immunosuppressive treatment for GVHD [167]. Taken together, these studies suggest that many allotransplanted patients already had reduced QoL when relapse was diagnosed, and this has to be considered when deciding the therapeutic strategy for relapse. This is especially important for patients with aggressive early relapse and shortened expected survival. In this context, it should also be emphasized that valproic acid/ATRA may have antileukemic effects even when the maximal tolerated dose is low and the recommended therapeutic serum level is not reached $[3,35,37,114,115]$.

\section{Summarizing Comments}

\subsection{Alternative Pharmacological Combinations}

Leukemia relapse is a common cause of death in allotransplanted AML patients. The risk of relapse may possibly be reduced by additional posttransplant chemotherapy, e.g., kinase inhibitors [168], low-dose or late lenalidomide [169], low-dose azacitidine [170,171] or its oral formulation CC-486 [172], decitabine [173], gemtuzumab [174], or prophylactic DLI in patients without clinical GVHD [175] (see the previous Table 5). Examination of posttransplant minimal residual disease may become useful to guide such therapeutic strategies [176,177]. Although these approached may reduce the risk of relapse, the treatment of posttransplant AML relapse will still be a challenge. Many of these patients are not fit for intensive treatment, and AML-stabilizing treatment will then be their only alternative. 
The efficiency of hypomethylating agents and especially azacitidine as an AMLstabilizing treatment for posttransplant AML relapse was documented in several clinical studies (Table 7) $[135,137,144-152]$. Even low-dose therapy can be effective, and the toxicity seems acceptable. Furthermore, ATRA has been incorporated in several clinical AML trials but not for allotransplant recipients and with divergence; taken together, these results suggest that ATRA therapy has low toxicity and may contribute to the antileukemic effect of combined treatment at least for certain patients or patient subsets [4]. The combination of valproic acid and ATRA has antileukemic activity and low toxicity [35,37]. Experimental studies also suggest that valproic acid (possibly in combination with ATRA) can be combined with other antileukemic agents (Table 7) [122,178-185]. The addition of these two agents to conventional chemotherapy (e.g., azacitidine and even a fourth antileukemic agent, for example venetoclax) should, in our opinion, be further explored in future clinical trials, and this is supported by our present case reports.

Table 7. Combination of valproic acid with other agents: a summary of experimental studies [122,178-185].

\begin{tabular}{cc}
\hline Study & Study Design \\
\hline $\begin{array}{c}\text { Liu et al. [178] } \\
\text { Cytarabine }\end{array}$ & $\begin{array}{c}\text { In vitro studies of AML cell lines and } \\
\text { primary human AML cell lines }\end{array}$ \\
Xie et al. [179] & Cytarabine \\
$\begin{array}{c}\text { In vitro studies of pediatric t }(8 ; 21) \\
\text { positive and negative AML cells }\end{array}$ \\
$\begin{array}{c}\text { Leitch et al. [180] } \\
\text { causing stalling of S-phase } \\
\text { replication forks }\end{array}$ & $\begin{array}{c}\text { AML cell lines and primary patient } \\
\text { cells evaluated in vitro and in } \\
\text { xenograft models }\end{array}$ \\
\hline
\end{tabular}

Blagitko-Dorfs et al. [122]

DNA methyl transferase inhibitors

AML cell lines
Xie et al. [185]

Clofarabine, a second generation

purine nucleoside analog
Pediatric cell lines and primary samples studied in vitro

\section{Observations}

Increased $B A X$ expression detected at the mRNA level leading to reduced AML cell proliferation, sub-G1 arrest, and apoptosis

$t(8 ; 21)$-positive cells were most susceptible to the combined treatment with induction of DNA double-stranded breaks together with induction of Bim-mediated and caspase-dependent apoptosis.

Valproic acid amplified the ability of hydroxyurea to slow S-phase progression; this effect was correlated with increased DNA damage. Reduced expression of the DNA repair protein Rad51

Combined treatment affected more transcripts than the sum of the genes altered by either treatment alone; downregulation of oncogenes and epigenetic modifiers

Synergistic antileukemic effects in cells sensitive to valproic acid with Bax activation and apoptosis; for valproic acid-resistant cells, antagonistic effects were observed.

Synergistic effects with G1 phase cell cycle arrest and induction of caspase-dependent apoptosis.

The effects seemed to be mediated by MEK/ERK and p38 MAP kinases.
AML cell lines and patient samples investigated in vitro

Cotreatment resulted in the induction of p53,

McCormack et al. [182]

Nutlin 3, a MDM2 antagonist
AML cell lines and patient cells tested in vitro and in xenograft models acetylated p53, and p53 target genes compared with either agent tested alone; this was followed by p53-dependent cell death with autophagic features.
Wang et al. [184]

Bortezomib, a proteasome inhibitor
In vitro studies of AML cell lines and primary AML cells
Antiproliferative and proapoptotic effects with increased mitochondrial injury and caspase activation. They observed reduced NFkB, Akt, and ERK signaling and activation of stress-induced pathways (e.g., JNK and p38). The combination caused G2/M arrest and increased p21.

G0/G1 arrest with induction of apoptosis, inhibition of cyclin D1, and telomerase activity
Nie et al. [183] Bortezomib
The HL60 cell line 


\subsection{Alternative HDAC Inhibitors}

Valproic acid as well as several other HDAC inhibitors are now considered for the treatment of AML, but even the newer inhibitors seem to have a limited antileukemic effect when used as monotherapy [186-188]. These new HDAC inhibitors should be further considered as possible alternatives to valproic acid for the treatment of posttransplant relapse, but one should emphasize that, for several of them, the toxicity has to be carefully considered because the side effects seem more severe than that for valproic acid [189,190]. However, for belinostat, the toxicity seems to be acceptable, at least for T cell lymphoma patients where fatigue and gastrointestinal toxicity are most frequent and the risk of severe hematological toxicity is low [191]. Finally, valproic acid modulates systemic metabolism, and such metabolic effects may contribute to antileukemic effects [5] and be unique for valproic acid (a fatty acid) compared to other HDAC inhibitors.

\subsection{Possible Effects on Graft Versus Leukemia (GVL) Effects}

As described in Sections 2 and 3, both ATRA and valproic acid have effects on several immunocompetent cells, and as outlined above, these drugs may also influence the risk of GVHD. The basis for the use of donor lymphocyte infusions in several of the clinical studies (see Section 7.1 and Table 6) is to increase antileukemic GVL activity without the development of severe GVHD $[2,134,143]$. It would not be surprising if the immunomodulatory effects of ATRA and/or valproic acid could influence posttransplant GVL activity, but to the best of our knowledge, this question has not been addressed in previous studies and it is difficult to provide an answer based on the available scientific literature.

Checkpoint inhibitors are now being tried in the treatment of AML [192]. This therapeutic strategy is also considered for posttransplant enhancement of antileukemic GVL activity, but the conclusion from small clinical studies is that this treatment can exacerbate GVHD [193]. The recently published experience for 209 patients with Hodgkin disease allotransplanted after PD-1 blockade may then be relevant [194]. The 180-day cumulative incidence of grade 3-4 acute GVHD was 15\% and the 2-year incidence of chronic GVHD was $34 \%$. Furthermore, a longer interval from PD-1 blockade to allotransplantation was associated with decreased risk of severe acute GVHD, whereas additional treatment between PD-1 blockade and transplantation was associated with increased relapse risk. Finally, the use of cyclophosphamide-based GVHD prophylaxis was associated with GVHD-free and relapse-free survival. These observations suggest that there is a risk of severe immunemediated toxicity when combining checkpoint inhibition and allotransplantation, but optimal timing and transplantation procedures seem to make combined treatment possible and therefore enhance posttransplant anticancer reactivity. However, it is not known whether it will be possible to use this strategy in AML and whether/how ATRA or valproic acid will interfere with such a GvL targeting therapy.

\section{Conclusions}

To answer our initial question, in our opinion, valproic acid and ATRA should be further investigated for the treatment of post-allotransplant AML relapse. It is a unique combination with antileukemic effects that may be mediated both through systemic metabolic modulation and through direct effects on the leukemic cells. However, neither of the two drugs should be used as monotherapy but should be used as a part of a low-toxicity AML-stabilizing treatment, especially for unfit patients, e.g., patients with reduced posttransplant quality of life. It should also be emphasized that reducing the risk of relapse through posttransplant antileukemic pharmacotherapy and/or DLI needs to be further explored $[130,143,195]$ together with alternative epigenetic strategies [196] and epigenetic approaches based on venetoclax [197]. 
Author Contributions: Patient treatment according to the clinical protocol, Ø.B., T.H.A.T., H.R. and G.T. All authors contributed to writing of the manuscript (Ø.B., G.T., M.H.-V., H.R., T.H.A.T.) and All authors have read and agreed to the published version of the manuscript.

Funding: This research was funded by The Norwegian Cancer Society grant number 100933.

Institutional Review Board Statement: Not applicable.

Informed Consent Statement: Not applicable.

Data Availability Statement: The data presented in this study are available upon request from the corresponding author.

Conflicts of Interest: The authors declare no conflict of interest.

\section{References}

1. Reivam, H.; Kittang, A.O.; Melve, G.; Mosevoll, K.A.; Bentsen, P.T.; Ersvaer, E.; Gjertsen, B.T.; Bruserud, Ø. Targeted anti-leukemic therapy as disease-stabilizing treatment for acute myeloid leukemia relapse after allogeneic stem cell transplantation: Will it be possible to combine these strategies with retransplantation or donor lymphocyte infusions? Curr. Cancer Drug Targets 2013, 13, 30-47. [CrossRef]

2. Rautenberg, C.; Germing, U.; Haas, R.; Kobbe, G.; Schroeder, T. Relapse of acute myeloid leukemia after allogeneic stem cell transplantation: Prevention, detection, and treatment. Int. J. Mol. Sci. 2019, 20, 228. [CrossRef]

3. Fredly, H.; Gjertsen, B.T.; Bruserud, $\varnothing$. Histone deacetylase inhibition in the treatment of acute myeloid leukemia: The effects of valproic acid on leukemic cells, and the clinical and experimental evidence for combining valproic acid with other antileukemic agents. Clin. Epigenetics 2013, 5, 12. [CrossRef] [PubMed]

4. Nguyen, C.H.; Grandits, A.M.; Purton, L.E.; Sill, H.; Wieser, R. All-trans retinoic acid in non-promyelocytic acute myeloid leukemia: Driver lesion dependent effects on leukemic stem cells. Cell. Cycle 2020, 19, 2573-2588. [CrossRef]

5. Gronningsaeter, I.S.; Fredly, H.K.; Gjertsen, B.T.; Hatfield, K.J.; Bruserud, Ø. Systemic metabolomic profiling of acute myeloid leukemia patients before and during disease-stabilizing treatment based on all-trans retinoic acid, valproic acid, and low-dose chemotherapy. Cells 2019, 8, 1229. [CrossRef]

6. Martino, O.D.; Welch, J.S. Retinoic acid receptors in acute myeloid leukemia therapy. Cancers 2019, 11, 1915. [CrossRef] [PubMed]

7. Acharya, S.; Bussel, J.B. Hematologic toxicity of sodium valproate. J. Pediatr. Hematol. Oncol. 2000, 22, 62-65. [CrossRef]

8. Zimran, E.; Papa, L.; Djedaini, M.; Patel, A.; Iancu-Rubin, C.; Hoffman, R. Expansion and preservation of the functional activity of adult hematopoietic stem cells cultured ex vivo with a histone deacetylase inhibitor. Stem. Cells. Transl. Med. 2020, 9, 531-542. [CrossRef]

9. Shah, R.R.; Koniski, A.; Shinde, M.; Blythe, S.A.; Fass, D.M.; Haggarty, S.J.; Palis, J.; Klein, P.S. Regulation of primitive hematopoiesis by class I histone deacetylases. Dev. Dyn. 2013, 242, 108-121. [CrossRef] [PubMed]

10. Chateauvieux, S.; Eifes, S.; Morceau, F.; Grigorakaki, C.; Schnekenburger, M.; Henry, E.; Dicato, M.; Diederich, M. Valproic acid perturbs hematopoietic homeostasis by inhibition of erythroid differentiation and activation of the myelo-monocytic pathway. Biochem. Pharmacol. 2011, 81, 498-509. [CrossRef]

11. Bug, G.; Gül, H.; Schwarz, K.; Pfeifer, H.; Kampfmann, M.; Zheng, X.; Beissert, T.; Boehrer, S.; Hoelzer, D.; Ottmann, O.G.; et al. Valproic acid stimulates proliferation and self-renewal of hematopoietic stem cells. Cancer Res. 2005, 65, 2537-2541. [CrossRef] [PubMed]

12. Passeri, D.; Marcucci, A.; Rizzo, G.; Billi, M.; Panigada, M.; Leonardi, L.; Tirone, F.; Grignani, F. Btg2 enhances retinoic acid-induced differentiation by modulating histone $\mathrm{H} 4$ methylation and acetylation. Mol. Cell. Biol. 2006, 26, 5023-5032. [CrossRef]

13. Urvalek, A.; Laursen, K.B.; Gudas, L.J. The roles of retinoic acid and retinoic acid receptors in inducing epigenetic changes. Subcell. Biochem. 2014, 70, 129-149. [PubMed]

14. Qi, H.; Ratnam, M. Synergistic induction of folate receptor beta by all-trans retinoic acid and histone deacetylase inhibitors in acute myelogenous leukemia cells: Mechanism and utility in enhancing selective growth inhibition by antifolates. Cancer Res. 2006, 66, 5875-5882. [CrossRef]

15. Trus, M.R.; Yang, L.; Suarez Saiz, F.; Bordeleau, L.; Jurisica, I.; Minden, M.D. The histone deacetylase inhibitor valproic acid alters sensitivity towards all trans retinoic acid in acute myeloblastic leukemia cells. Leukemia 2005, 19, 1161-1168. [CrossRef]

16. Lakshmaiah, K.C.; Jacob, L.A.; Aparna, S.; Lokanatha, D.; Saldanha, S.C. Epigenetic therapy of cancer with histone deacetylase inhibitors. J. Cancer Res. Ther. 2014, 10, 469-478.

17. Chateauvieux, S.; Morceau, F.; Dicato, M.; Diederich, M. Molecular and therapeutic potential and toxicity of valproic acid. J. Biomed. Biotechnol. 2010, 2010, 479364. [CrossRef] [PubMed]

18. Bradbury, C.A.; Khanim, F.L.; Hayden, R.; Bunce, C.M.; White, D.A.; Drayson, M.T.; Craddock, C.; Turner, B.M. Histone deacetylases in acute myeloid leukaemia show a distinctive pattern of expression that changes selectively in response to deacetylase inhibitors. Leukemia 2005, 19, 1751-1759. [CrossRef] 
19. Lübbert, M.; Grishina, O.; Schmoor, C.; Schlenk, R.F.; Jost, E.; Crysandt, M.; Heuser, M.; Thol, F.; Salih, H.R.; Schittenhelm, M.M.; et al. DECIDER study team. Valproate and retinoic acid in combination with decitabine in elderly nonfit patients with acute myeloid leukemia: Results of a multicenter, randomized, $2 \times 2$, Phase II Trial. J. Clin. Oncol. 2020, 38, 257-270. [CrossRef]

20. Zhang, Z.H.; Hao, C.L.; Liu, P.; Tian, X.; Wang, L.H.; Zhao, L.; Zhu, C.-M. Valproic acid inhibits tumor angiogenesis in mice transplanted with Kasumi1 leukemia cells. Mol. Med. Rep. 2014, 9, 443-449. [CrossRef]

21. Liu, S.; Klisovic, R.B.; Vukosavljevic, T.; Yu, J.; Paschka, P.; Huynh, L.; Pang, J.; Neviani, P.; Liu, Z.; Blum, W.; et al. Targeting AML1/ETO-histone deacetylase repressor complex: A novel mechanism for valproic acid-mediated gene expression and cellular differentiation in AML1/ETO-positive acute myeloid leukemia cells. J. Pharmacol. Exp. Ther. 2007, 321, 953-960. [CrossRef] [PubMed]

22. Ryningen, A.; Stapnes, C.; Paulsen, K.; Lassalle, P.; Gjertsen, B.T.; Bruserud, Ø. In vivo biological effects of ATRA in the treatment of AML. Expert. Opin. Investig. Drugs 2008, 17, 1623-1633. [CrossRef] [PubMed]

23. Davood, Z.A.; Shamsi, S.; Ghaedi, H.; Sahand, R.I.; Mojtaba, G.; Mahdi, T.; Reza, M.; Ebrahimi, M.J.; Miri-Moosavi, R.S.; Boosaliki, S.; et al. Valproic acid may exerts its cytotoxic effect through rassf1a expression induction in acute myeloid leukemia. Tumour. Biol. 2016, 37, 11001-11006. [CrossRef] [PubMed]

24. Forthun, R.B.; Sengupta, T.; Skjeldam, H.K.; Lindvall, J.M.; McCormack, E.; Gjertsen, B.T.; Nilsen, H. Cross-species functional genomic analysis identifies resistance genes of the histone deacetylase inhibitor valproic acid. PLoS ONE 2012,7 , e48992.

25. Gul, H.; Marquez-Curtis, L.A.; Jahroudi, N.; Larratt, L.M.; Janowska-Wieczorek, A. Valproic acid exerts differential effects on CXCR4 expression in leukemic cells. Leuk. Res. 2010, 34, 235-242. [CrossRef]

26. Stapnes, C.; Ryningen, A.; Hatfield, K.; Øyan, A.M.; Eide, G.E.; Corbascio, M.; Kalland, K.H.; Gjertsen, B.T.; Bruserud, Ø. Functional characteristics and gene expression profiles of primary acute myeloid leukaemia cells identify patient subgroups that differ in susceptibility to histone deacetylase inhibitors. Int. J. Oncol. 2007, 31, 1529-1538. [CrossRef]

27. Cimino, G.; Lo-Coco, F.; Fenu, S.; Travaglini, L.; Finolezzi, E.; Mancini, M.; Nanni, M.; Careddu, A.; Fazi, F.; Padula, F.; et al. Sequential valproic acid/all-trans retinoic acid treatment reprograms differentiation in refractory and high-risk acute myeloid leukemia. Cancer Res. 2006, 66, 8903-8911. [CrossRef]

28. Reikvam, H.; Hovland, R.; Forthun, R.B.; Erdal, S.; Gjertsen, B.T.; Fredly, H.; Bruserud, Ø. Disease-stabilizing treatment based on all-trans retinoic acid and valproic acid in acute myeloid leukemia-identification of responders by gene expression profiling of pretreatment leukemic cells. BMC Cancer 2017, 17, 630. [CrossRef]

29. Rücker, F.G.; Lang, K.M.; Fütterer, M.; Komarica, V.; Schmid, M.; Döhner, H.; Schlenk, R.F.; Döhner, K.; Knudsen, S.; Bullinger, L. Molecular dissection of valproic acid effects in acute myeloid leukemia identifies predictive networks. Epigenetics 2016, 11, 517-525. [CrossRef]

30. Zhang, Z.; Hao, C.; Wang, L.; Liu, P.; Zhao, L.; Zhu, C.; Tian, X. Inhibition of leukemic cells by valproic acid, an HDAC inhibitor, in xenograft tumors. Onco. Targets Ther. 2013, 6, 733-740.

31. Forthun, R.B.; Hellesøy, M.; Sulen, A.; Kopperud, R.K.; Sjøholt, G.; Bruserud, Ø.; McCormack, E.; Gjertsen, B.T. Modulation of phospho-proteins by interferon-alpha and valproic acid in acute myeloid leukemia. J. Cancer Res. Clin. Oncol. 2019, 145, 1729-1749. [CrossRef]

32. Hernandez-Valladares, M.; Wangen, R.; Aasebø, E.; Reikvam, H.; Berven, F.S.; Selheim, F.; Bruserud, Ø. Proteomic studies of primary acute myeloid leukemia cells derived from patients before and during disease-stabilizing treatment based on all-trans retinoic acid and valproic acid. Cancers 2021, 13, 2143. [CrossRef]

33. Cho, H.H.; Park, H.T.; Kim, Y.; Bae, Y.C.; Suh, K.T.; Jung, J.S. Induction of osteogenic differentiation of human mesenchymal stem cells by histone deacetylase inhibitors. J. Cell. Biochem. 2005, 96, 533-542. [CrossRef] [PubMed]

34. Kvestad, H.; Evensen, L.; Lorens, J.B.; Bruserud, Ø.; Hatfield, K.J. In Vitro characterization of valproic acid, atra, and cytarabine used for disease-stabilization in human acute myeloid leukemia: Antiproliferative effects of drugs on endothelial and osteoblastic cells and altered release of angioregulatory mediators by endothelial cells. Leuk. Res. Treat. 2014, 2014, 143479.

35. Ryningen, A.; Stapnes, C.; Lassalle, P.; Corbascio, M.; Gjertsen, B.T.; Bruserud, Ø. A subset of patients with high-risk acute myelogenous leukemia shows improved peripheral blood cell counts when treated with the combination of valproic acid, theophylline and all-trans retinoic acid. Leuk. Res. 2009, 33, 779-787. [CrossRef]

36. Ersvaer, E.; Brenner, A.K.; Vetas, K.; Reikvam, H.; Bruserud, Ø. Effects of cytarabine on activation of human T cells-Cytarabine has concentration-dependent effects that are modulated both by valproic acid and all-trans retinoic acid. BMC Pharmacol. Toxicol. 2015, 16, 12. [CrossRef] [PubMed]

37. Fredly, H.; Ersvaer, E.; Kittang, A.O.; Tsykunova, G.; Gjertsen, B.T.; Bruserud, Ø. The combination of valproic acid, all-trans retinoic acid and low-dose cytarabine as disease-stabilizing treatment in acute myeloid leukemia. Clin. Epigenetics $2013,5,13$. [CrossRef]

38. Arbez, J.; Lamarthee, B.; Gaugler, B.; Saas, P. Histone deacetylase inhibitor valproic acid affects plasmacytoid dendritic cells phenotype and function. Immunobiology 2014, 219, 637-643. [CrossRef]

39. Leu, S.J.; Yang, Y.Y.; Liu, H.C.; Cheng, C.Y.; Wu, Y.C.; Huang, M.C.; Lee, Y.L.; Chen, C.C.; Shen, W.W.; Liu, K.J. Valproic acid and lithium meditate anti-inflammatory effects by differentially modulating dendritic cell differentiation and function. J. Cell. Physiol. 2017, 232, 1176-1186. [CrossRef]

40. Frikeche, J.; Simon, T.; Brissot, E.; Gregoire, M.; Gaugler, B.; Mohty, M. Impact of valproic acid on dendritic cells function. Immunobiology 2012, 217, 704-710. [CrossRef] 
41. Nencioni, A.; Beck, J.; Werth, D.; Grünebach, F.; Patrone, F.; Ballestrero, A.; Brossart, P. Histone deacetylase inhibitors affect dendritic cell differentiation and immunogenicity. Clin. Cancer Res. 2007, 13, 3933-3941. [CrossRef] [PubMed]

42. Delgado, F.G.; Cardenas, P.; Castellanos, J.E. Valproic acid downregulates cytokine expression in human macrophages infected with dengue virus. Diseases 2018, 6, 59. [CrossRef]

43. Mohammadi, S.; Saghaeian-Jazi, M.; Sedighi, S.; Memarian, A. Sodium valproate modulates immune response by alternative activation of monocyte-derived macrophages in systemic lupus erythematosus. Clin. Rheumatol. 2018, 37, 719-727. [CrossRef] [PubMed]

44. Killer, M.C.; Nold, P.; Henkenius, K.; Fritz, L.; Riedlinger, T.; Barckhausen, C.; Frech, M.; Hackstein, H.; Neubauer, A.; Brendel, C. Immunosuppressive capacity of mesenchymal stem cells correlates with metabolic activity and can be enhanced by valproic acid. Stem. Cell. Res. Ther. 2017, 8, 100. [CrossRef]

45. Bidkhori, H.R.; Ahmadiankia, N.; Matin, M.M.; Heirani-Tabasi, A.; Farshchian, M.; Naderi-Meshkin, H.; Shahriyari, M.; Dastpak, M.; Bahrami, A.R. Chemically primed bone-marrow derived mesenchymal stem cells show enhanced expression of chemokine receptors contributed to their migration capability. Iran. J. Basic Med. Sci. 2016, 19, 14-19. [PubMed]

46. Fredly, H.; Reikvam, H.; Gjertsen, B.T.; Bruserud, Ø. Disease-stabilizing treatment with all-trans retinoic acid and valproic acid in acute myeloid leukemia: Serum hsp70 and hsp90 levels and serum cytokine profiles are determined by the disease, patient age, and anti-leukemic treatment. Am. J. Hematol. 2012, 87, 368-376. [CrossRef]

47. Pulliam, S.R.; Pellom, S.T., Jr.; Shanker, A.; Adunyah, S.E. Butyrate regulates the expression of inflammatory and chemotactic cytokines in human acute leukemic cells during apoptosis. Cytokine 2016, 84, 74-87. [CrossRef] [PubMed]

48. Myzak, M.C.; Dashwood, R.H. Histone deacetylases as targets for dietary cancer preventive agents: Lessons learned with butyrate, diallyl disulfide, and sulforaphane. Curr. Drug Targets 2006, 7, 443-452. [CrossRef]

49. Heidor, R.; Ortega, J.F.; de Conti, A.; Ong, T.P.; Moreno, F.S. Anticarcinogenic actions of tributyrin, a butyric acid prodrug. Curr Drug Targets 2012, 13, 1720-1729. [CrossRef]

50. Brenner, A.K.; Bruserud, Ø. Functional Toll-Like Receptors (TLRs) are expressed by a majority of primary human acute myeloid leukemia cells and inducibility of the tlr signaling pathway is associated with a more favorable phenotype. Cancers 2019, 11, 973. [CrossRef]

51. Kopp, A.; Buechler, C.; Bala, M.; Neumeier, M.; Schölmerich, J.; Schäffler, A. Toll-like receptor ligands cause proinflammatory and prodiabetic activation of adipocytes via phosphorylation of extracellular signal-regulated kinase and c-Jun N-terminal kinase but not interferon regulatory factor-3. Endocrinology 2010, 151, 1097-1108. [CrossRef]

52. Botteri, G.; Montori, M.; Gumà, A.; Pizarro, J.; Cedó, L.; Escolà-Gil, J.C.; Li, D.; Barroso, E.; Palomer, X.; Kohan, A.B.; et al. VLDL and apolipoprotein CIII induce ER stress and inflammation and attenuate insulin signalling via Toll-like receptor 2 in mouse skeletal muscle cells. Diabetologia 2017, 60, 2262-2273. [CrossRef]

53. Kawakami, A.; Yoshida, M. Apolipoprotein CIII links dyslipidemia with atherosclerosis. J. Atheroscler. Thromb. 2009, 16, 6-11. [CrossRef]

54. Van Gils, N.; Verhagen, H.J.M.P.; Smit, L. Reprogramming acute myeloid leukemia into sensitivity for retinoic-acid-driven differentiation. Exp. Hematol. 2017, 52, 12-23. [CrossRef]

55. Rossetti, S.; Sacchi, N. Emerging cancer epigenetic mechanisms regulated by all-trans retinoic acid. Cancers 2020, $12,2275$. [CrossRef]

56. Giuli, M.V.; Hanieh, P.N.; Giuliani, E.; Rinaldi, F.; Marianecci, C.; Screpanti, I.; Checquolo, S.; Carafa, M. Current trends in ATRA delivery for cancer therapy. Pharmaceutics 2020, 12, 707. [CrossRef] [PubMed]

57. Wang, D.; Zeng, T.; Lin, Z.; Yan, L.; Wang, F.; Tang, L.; Wang, L.; Tang, D.; Chen, P.; Yang, M. Long non-coding RNA SNHG5 regulates chemotherapy resistance through the miR-32/DNAJB9 axis in acute myeloid leukemia. Biomed. Pharm. 2020, 123, 109802 [CrossRef] [PubMed]

58. Nguyen, C.H.; Grandits, A.M.; Vassiliou, G.S.; Staber, P.B.; Heller, G.; Wieser, R. Evi1 Counteracts anti-leukemic and stem cell inhibitory effects of all-trans retinoic acid on Flt3-ITD/Npm1Driven acute myeloid leukemia cells. Biomedicines $2020,8,385$. [CrossRef] [PubMed]

59. Schlenk, R.F.; Fröhling, S.; Hartmann, F.; Fischer, J.T.; Glasmacher, A.; del Valle, F.; Grimminger, W.; Götze, K.; Waterhouse, C.; Schoch, R.; et al. Study Group Ulm. Phase III study of all-trans retinoic acid in previously untreated patients 61 years or older with acute myeloid leukemia. Leukemia 2004, 18, 1798-1803. [CrossRef]

60. Schlenk, R.F.; Döhner, K.; Kneba, M.; Götze, K.; Hartmann, F.; Del Valle, F.; Kirchen, H.; Koller, E.; Fischer, J.T.; Bullinger, L.; et al. Gene mutations and response to treatment with all-trans retinoic acid in elderly patients with acute myeloid leukemia. Results from the AMLSG Trial AML HD98B. Haematologica 2009, 94, 54-60. [CrossRef]

61. Heuser, M.; Argiropoulos, B.; Kuchenbauer, F.; Yung, E.; Piper, J.; Fung, S.; Schlenk, R.F.; Dohner, K.; Hinrichsen, T.; Rudolph, C.; et al. MN1 overexpression induces acute myeloid leukemia in mice and predicts ATRA resistance in patients with AML. Blood 2007, 110, 1639-1647. [CrossRef] [PubMed]

62. Burnett, A.K.; Hills, R.K.; Green, C.; Jenkinson, S.; Koo, K.; Patel, Y.; Guy, C.; Gilkes, A.; Milligan, D.W.; Goldstone, A.H.; et al. The impact on outcome of the addition of all-trans retinoic acid to intensive chemotherapy in younger patients with nonacute promyelocytic acute myeloid leukemia: Overall results and results in genotypic subgroups defined by mutations in NPM1, FLT3, and CEBPA. Blood 2010, 115, 948-956. [PubMed] 
63. Schlenk, R.F.; Lübbert, M.; Benner, A.; Lamparter, A.; Krauter, J.; Herr, W.; Martin, H.; Salih, H.R.; Kündgen, A.; Horst, H.A.; et al. All-trans retinoic acid as adjunct to intensive treatment in younger adult patients with acute myeloid leukemia: Results of the randomized AMLSG 07-04 study. Ann. Hematol. 2016, 95, 1931-1942. [CrossRef] [PubMed]

64. Küley-Bagheri, Y.; Kreuzer, K.A.; Monsef, I.; Lübbert, M.; Skoetz, N. Effects of all-trans retinoic acid (ATRA) in addition to chemotherapy for adults with acute myeloid leukaemia (AML) (non-acute promyelocytic leukaemia (non-APL)). Cochrane Database Syst. Rev. 2018, 8, CD011960. [CrossRef] [PubMed]

65. McKeown, M.R.; Johannessen, L.; Lee, E.; Fiore, C.; di Tomaso, E. Antitumor synergy with SY-1425, a selective RAR $\alpha$ agonist, and hypomethylating agents in retinoic acid receptor pathway activated models of acute myeloid leukemia. Haematologica 2019, 104, e138-e142. [CrossRef] [PubMed]

66. Fazi, F.; Zardo, G.; Gelmetti, V.; Travaglini, L.; Ciolfi, A.; Di Croce, L.; Rosa, A.; Bozzoni, I.; Grignani, F.; Lo-Coco, F.; et al. Heterochromatic gene repression of the retinoic acid pathway in acute myeloid leukemia. Blood 2007, 109, 4432-4440. [CrossRef]

67. Su, M.; Alonso, S.; Jones, J.W.; Yu, J.; Kane, M.A.; Jones, R.J.; Ghiaur, G. All-trans retinoic acid activity in acute myeloid leukemia: Role of cytochrome P450 enzyme expression by the microenvironment. PLoS ONE 2015, 10, e127790. [CrossRef]

68. Martelli, M.P.; Gionfriddo, I.; Mezzasoma, F.; Milano, F.; Pierangeli, S.; Mulas, F.; Pacini, R.; Tabarrini, A.; Pettirossi, V.; Rossi, R.; et al. Arsenic trioxide and all-trans retinoic acid target NPM1 mutant oncoprotein levels and induce apoptosis in NPM1-mutated AML cells. Blood 2015, 125, 3455-3465. [CrossRef]

69. El Hajj, H.; Dassouki, Z.; Berthier, C.; Raffoux, E.; Ades, L.; Legrand, O.; Hleihel, R.; Sahin, U.; Tawil, N.; Salameh, A.; et al. Retinoic acid and arsenic trioxide trigger degradation of mutated NPM1, resulting in apoptosis of AML cells. Blood 2015, 125, 3447-3454. [CrossRef]

70. Boutzen, H.; Saland, E.; Larrue, C.; de Toni, F.; Gales, L.; Castelli, F.A.; Cathebas, M.; Zaghdoudi, S.; Stuani, L.; Kaoma, T.; et al. Isocitrate dehydrogenase 1 mutations prime the all-trans retinoic acid myeloid differentiation pathway in acute myeloid leukemia. J. Exp. Med. 2016, 213, 483-497. [CrossRef]

71. Haas, K.; Kundi, M.; Sperr, W.R.; Esterbauer, H.; Ludwig, W.D.; Ratei, R.; Koller, E.; Gruener, H.; Sauerland, C.; Fonatsch, C.; et al. Expression and prognostic significance of different mRNA 5'-end variants of the oncogene EVI1 in 266 patients with de novo AML: EVI1 and MDS1/EVI1 overexpression both predict short remission duration. Genes Chromosom. Cancer 2008, 47, 288-298. [CrossRef] [PubMed]

72. Lugthart, S.; van Drunen, E.; van Norden, Y.; van Hoven, A.; Erpelinck, C.A.; Valk, P.J.; Beverloo, H.B.; Löwenberg, B.; Delwel, R. High EVI1 levels predict adverse outcome in acute myeloid leukemia: Prevalence of EVI1 overexpression and chromosome $3 q 26$ abnormalities underestimated. Blood 2008, 111, 4329-4337. [CrossRef]

73. Gröschel, S.; Lugthart, S.; Schlenk, R.F.; Valk, P.J.; Eiwen, K.; Goudswaard, C.; van Putten, W.J.; Kayser, S.; Verdonck, L.F.; Lübbert, M.; et al. High EVI1 expression predicts outcome in younger adult patients with acute myeloid leukemia and is associated with distinct cytogenetic abnormalities. J. Clin. Oncol. 2010, 28, 2101-2107. [CrossRef]

74. Xi, Z.F.; Russell, M.; Woodward, S.; Thompson, F.; Wagner, L.; Taetle, R. Expression of the Zn finger gene, EVI-1, in acute promyelocytic leukemia. Leukemia 1997, 11, 212-220. [CrossRef]

75. Aytekin, M.; Vinatzer, U.; Musteanu, M.; Raynaud, S.; Wieser, R. Regulation of the expression of the oncogene EVI1 through the use of alternative mRNA 5'-ends. Gene 2005, 356, 160-168. [CrossRef] [PubMed]

76. Bingemann, S.C.; Konrad, T.A.; Wieser, R. Zinc finger transcription factor ecotropic viral integration site 1 is induced by all-trans retinoic acid (ATRA) and acts as a dual modulator of the ATRA response. FEBS J. 2009, 276, 6810-6822. [CrossRef]

77. Steinmetz, B.; Hackl, H.; Slabáková, E.; Schwarzinger, I.; Smějová, M.; Spittler, A.; Arbesu, I.; Shehata, M.; Souček, K.; Wieser, R. The oncogene EVI1 enhances transcriptional and biological responses of human myeloid cells to all-trans retinoic acid. Cell. Cycle 2014, 13, 2931-2943. [CrossRef]

78. Verhagen, H.J.; Smit, M.A.; Rutten, A.; Denkers, F.; Poddighe, P.J.; Merle, P.A.; Ossenkoppele, G.J.; Smit, L. Primary acute myeloid leukemia cells with overexpression of EVI-1 are sensitive to all-trans retinoic acid. Blood 2016, 127, 458-463. [CrossRef]

79. Nguyen, C.H.; Bauer, K.; Hackl, H.; Schlerka, A.; Koller, E.; Hladik, A.; Stoiber, D.; Zuber, J.; Staber, P.B.; Hoelbl-Kovacic, A.; et al. All-trans retinoic acid enhances, and a pan-RAR antagonist counteracts, the stem cell promoting activity of EVI1 in acute myeloid leukemia. Cell Death Dis. 2019, 10, 944. [CrossRef] [PubMed]

80. Moreb, J.-S.; Ucar-Bilyeu, D.A.; Khan, A. Use of retinoic acid/aldehyde dehydrogenase pathway as potential targeted therapy against cancer stem cells. Cancer Chemother. Pharm. 2017, 79, 295-301. [CrossRef] [PubMed]

81. Gasparetto, M.; Smith, C.A. ALDHs in normal and malignant hematopoietic cells: Potential new avenues for treatment of AML and other blood cancers. Chem. Biol. Interact. 2017, 276, 46-51. [CrossRef]

82. Hernandez-Valladares, M.; Aasebø, E.; Berven, F.; Selheim, F.; Bruserud, $\varnothing$. Biological characteristics of aging in human acute myeloid leukemia cells: The possible importance of aldehyde dehydrogenase, the cytoskeleton and altered transcriptional regulation. Aging 2020, 12, 24734-24777. [CrossRef] [PubMed]

83. Rundberg Nilsson, A.; Pronk, C.J. Retinoic acid puts hematopoietic stem cells back to sleep. Cell. Stem. Cell. 2017, $21,9-11$. [CrossRef] [PubMed]

84. Cañete, A.; Cano, E.; Muñoz-Chápuli, R.; Carmona, R. Role of vitamin A/retinoic acid in regulation of embryonic and adult hematopoiesis. Nutrients 2017, 9, 159. [CrossRef]

85. Bono, M.R.; Tejon, G.; Flores-Santibañez, F.; Fernandez, D.; Rosemblatt, M.; Sauma, D. Retinoic acid as a modulator of $\mathrm{t}$ cell immunity. Nutrients 2016, 8, 349. [CrossRef] 
86. Xie, L.; Zou, L.; Chen, J.; Liu, Y. All-trans retinoic acid inhibits bone marrow mesenchymal stem cell commitment to adipocytes via upregulating FRA1 signaling. Int. J. Endocrinol. 2020, 2020, 6525787. [CrossRef]

87. Sun, W.; Shi, A.; Ma, D.; Bolscher, J.G.M.; Nazmi, K.; Veerman, E.C.I.; Bikker, F.J.; Lin, H.; Wu, G. All-trans retinoic acid and human salivary histatin-1 promote the spreading and osteogenic activities of pre-osteoblasts in vitro. FEBS Open Bio 2020, 10, 396-406. [CrossRef] [PubMed]

88. Liu, Y.; Ma, X.; Guo, J.; Lin, Z.; Zhou, M.; Bi, W.; Liu, J.; Wang, J.; Lu, H.; Wu, G. All-trans retinoic acid can antagonize osteoblastogenesis induced by different BMPs irrespective of their dimerization types and dose-efficiencies. Drug Des. Devel. Ther. 2018, 12, 3419-3430. [CrossRef] [PubMed]

89. Pawlikowski, B.; Wragge, J.; Siegenthaler, J.A. Retinoic acid signaling in vascular development. Genesis 2019, 57, e23287. [CrossRef]

90. Li, N.; Lu, Y.; Li, D.; Zheng, X.; Lian, J.; Li, S.; Cui, H.; Zhang, L.; Sang, L.; Wang, Y.; et al. All-trans retinoic acid suppresses the angiopoietin-Tie2 pathway and inhibits angiogenesis and metastasis in esophageal squamous cell carcinoma. PLoS ONE 2017, 12, e0174555. [CrossRef] [PubMed]

91. Erkelens, M.N.; Mebius, R.E. Retinoic acid and immune homeostasis: A balancing act. Trends Immunol. 2017, 38, 168-180. [CrossRef] [PubMed]

92. Huang, Z.; Liu, Y.; Qi, G.; Brand, D.; Zheng, S.G. Role of vitamin A in the immune system. J. Clin. Med. 2018, 7, 258. [CrossRef] [PubMed]

93. Oliveira, L.M.; Teixeira, F.M.E.; Sato, M.N. Impact of retinoic acid on immune cells and inflammatory diseases. Mediat. Inflamm. 2018, 2018, 3067126. [CrossRef]

94. Raverdeau, M.; Mills, K.H. Modulation of T cell and innate immune responses by retinoic Acid. J. Immunol. 2014, 192, $2953-2958$. [CrossRef]

95. Ross, A.C. Vitamin A and retinoic acid in T cell-related immunity. Am. J. Clin. Nutr. 2012, 96, 1166S-1172S. [CrossRef]

96. Sun, X.; Xiao, Y.; Zeng, Z.; Shi, Y.; Tang, B.; Long, H.; Kanekura, T.; Wang, J.; Wu, H.; Zhao, M.; et al. All-trans retinoic acid induces CD4+CD25+FOXP3+ regulatory T cells by increasing FOXP3 demethylation in systemic sclerosis CD4+ T cells. J. Immunol. Res. 2018, 2018, 8658156. [CrossRef] [PubMed]

97. Yin, W.; Song, Y.; Liu, Q.; Wu, Y.; He, R. Topical treatment of all-trans retinoic acid inhibits murine melanoma partly by promoting $\mathrm{CD}^{+}$T-cell immunity. Immunology 2017, 152, 287-297. [CrossRef]

98. Long, A.H.; Highfill, S.L.; Cui, Y.; Smith, J.P.; Walker, A.J.; Ramakrishna, S.; El-Etriby, R.; Galli, S.; Tsokos, M.G.; Orentas, R.J.; et al. Reduction of MDSCs with all-trans retinoic acid improves CAR therapy efficacy for sarcomas. Cancer Immunol. Res. 2016, 4 , 869-880. [CrossRef] [PubMed]

99. Vellozo, N.S.; Pereira-Marques, S.T.; Cabral-Piccin, M.P.; Filardy, A.A.; Ribeiro-Gomes, F.L.; Rigoni, T.S.; DosReis, G.A.; Lopes, M.F. All-Trans retinoic acid promotes an M1- to M2-phenotype shift and inhibits macrophage-mediated immunity to leishmania major. Front. Immunol. 2017, 8, 1560. [CrossRef] [PubMed]

100. Melve, G.K.; Ersvssr, E.; Kittang, A.O.; Bruserud, Ø. The chemokine system in allogeneic stem-cell transplantation: A possible therapeutic target? Expert Rev. Hematol. 2011, 4, 563-576. [CrossRef] [PubMed]

101. Rundgren, I.M.; Ersvær, E.; Ahmed, A.B.; Ryningen, A.; Bruserud, Ø. A Pilot Study of Circulating Monocyte Subsets in Patients Treated with Stem Cell Transplantation for High-Risk Hematological Malignancies. Medicina 2020, 56, 36. [CrossRef] [PubMed]

102. Rundgren, I.M.; Ersvær, E.; Ahmed, A.B.; Ryningen, A.; Bruserud, Ø. Circulating monocyte subsets in multiple myeloma patients receiving autologous stem cell transplantation-A study of the preconditioning status and the course until posttransplant reconstitution for a consecutive group of patients. BMC Immunol. 2019, 20, 39. [CrossRef] [PubMed]

103. Tvedt, T.H.A.; Skaarud, K.J.; Tjønnfjord, G.E.; Gedde-Dahl, T.; Iversen, P.O.; Bruserud, Ø. The systemic metabolic profile early after allogeneic stem cell transplantation: Effects of adequate energy support administered through enteral feeding tube. Biol. Blood Marrow. Transplant. 2020, 26, 380-391. [CrossRef] [PubMed]

104. Martinez-Cibrian, N.; Zeiser, R.; Perez-Simon, J.A. Graft-versus-host disease prophylaxis: Pathophysiology-based review on current approaches and future directions. Blood Rev. 2020, 100792, Epub ahead of print. [CrossRef]

105. Kim, M.H.; Taparowsky, E.J.; Kim, C.H. Retinoic acid differentially regulates the migration of innate lymphoid cell subsets to the gut. Immunity 2015, 43, 107-119. [CrossRef]

106. Czarnewski, P.; Das, S.; Parigi, S.M.; Villablanca, E.J. Retinoic acid and its role in modulating intestinal innate immunity. Nutrients 2017, 9, 68. [CrossRef]

107. Koenecke, C.; Prinz, I.; Bubke, A.; Schreder, A.; Lee, C.W.; Pabst, O.; Förster, R. Shift of graft-versus-host-disease target organ tropism by dietary vitamin A. PLoS ONE 2012, 7, e38252. [CrossRef]

108. Dodge, J.; Stephans, A.; Lai, J.; Drobyski, W.R.; Chen, X. Effects of donor vitamin a deficiency and pharmacologic modulation of donor $\mathrm{t}$ cell retinoic acid pathway on the severity of experimental graft-versus-host disease. Biol. Blood Marrow. Transpl. 2016, 22, 2141-2148. [CrossRef]

109. Chen, X.; Dodge, J.; Komorowski, R.; Drobyski, W.R. A critical role for the retinoic acid signaling pathway in the pathophysiology of gastrointestinal graft-versus-host disease. Blood 2013, 121, 3970-3980. [CrossRef]

110. Thangavelu, G.; Lee, Y.C.; Loschi, M.; Schaechter, K.M.; Feser, C.J.; Koehn, B.H.; Nowak, E.C.; Zeiser, R.; Serody, J.S.; Murphy, W.J.; et al. Dendritic cell expression of retinal aldehyde dehydrogenase-2 controls graft-versus-host disease lethality. J. Immunol. 2019, 202, 2795-2805. [CrossRef] 
111. Lounder, D.T.; Khandelwal, P.; Dandoy, C.E.; Jodele, S.; Grimley, M.S.; Wallace, G.; Lane, A.; Taggart, C.; Teusink-Cross, A.C.; Lake, K.E.; et al. Lower levels of vitamin A are associated with increased gastrointestinal graft-versus-host disease in children. Blood 2017, 129, 2801-2807. [CrossRef]

112. Tong, J.; Hu, R.; Zhao, Y.; Xu, Y.; Zhao, X.; Jin, X. Serum vitamin a levels may affect the severity of ocular graft-versus-host disease. Front. Med. 2017, 4, 67. [CrossRef] [PubMed]

113. Kuendgen, A.; Bug, G.; Ottmann, O.G.; Haase, D.; Schanz, J.; Hildebrandt, B.; Nachtkamp, K.; Neukirchen, J.; Dienst, A.; Haas, R.; et al. Treatment of poor-risk myelodysplastic syndromes and acute myeloid leukemia with a combination of 5azacytidine and valproic acid. Clin. Epigenetics 2011, 2, 389-399. [CrossRef]

114. Kuendgen, A.; Schmid, M.; Schlenk, R.; Knipp, S.; Hildebrandt, B.; Steidl, C.; Germing, U.; Haas, R.; Dohner, H.; Gattermann, N. The histone deacetylase (HDAC) inhibitor valproic acid as monotherapy or in combination with all-trans retinoic acid in patients with acute myeloid leukemia. Cancer 2006, 106, 112-119. [CrossRef]

115. Kuendgen, A.; Knipp, S.; Fox, F.; Strupp, C.; Hildebrandt, B.; Steidl, C.; Germing, U.; Haas, R.; Gattermann, N. Results of a phase 2 study of valproic acid alone or in combination with all-trans retinoic acid in 75 patients with myelodysplastic syndrome and relapsed or refractory acute myeloid leukemia. Ann. Hematol. 2005, 84, 61-66. [CrossRef] [PubMed]

116. Bug, G.; Schwarz, K.; Schoch, C.; Kampfmann, M.; Henschler, R.; Hoelzer, D.; Ottmann, O.G.; Ruthardt, M. Effect of histone deacetylase inhibitor valproic acid on progenitor cells of acute myeloid leukemia. Haematologica 2007, 92, 542-545. [CrossRef] [PubMed]

117. Bug, G.; Ritter, M.; Wassmann, B.; Schoch, C.; Heinzel, T.; Schwarz, K.; Romanski, A.; Kramer, O.H.; Kampfmann, M.; Hoelzer, D.; et al. Clinical trial of valproic acid and all-trans retinoic acid in patients with poor-risk acute myeloid leukemia. Cancer 2005, 104, 2717-2725. [CrossRef]

118. Raffoux, E.; Chaibi, P.; Dombret, H.; Degos, L. Valproic acid and all-trans retinoic acid for the treatment of elderly patients with acute myeloid leukemia. Haematologica 2005, 90, 986-988.

119. Lane, S.; Gill, D.; McMillan, N.A.; Saunders, N.; Murphy, R.; Spurr, T.; Keane, C.; Fan, H.M.; Mollee, P. Valproic acid combined with cytosine arabinoside in elderly patients with acute myeloid leukemia has in vitro but limited clinical activity. Leuk. Lymphoma 2012, 53, 1077-1083. [CrossRef]

120. Corsetti, M.T.; Salvi, F.; Perticone, S.; Baraldi, A.; De Paoli, L.; Gatto, S.; Pietrasanta, D.; Pini, M.; Primon, V.; Zallio, F.; et al. Hematologic improvement and response in elderly AML/RAEB patients treated with valproic acid and low-dose Ara-C. Leuk. Res. 2011, 35, 991-997. [CrossRef]

121. Xie, C.; Drenberg, C.; Edwards, H.; Caldwell, J.T.; Chen, W.; Inaba, H.; Xu, X.; Buck, S.A.; Taub, J.W.; Baker, S.D.; et al. Panobinostat enhances cytarabine and daunorubicin sensitivities in AML cells through suppressing the expression of BRCA1, CHK1, and Rad51. PLoS ONE 2013, 8, e79106. [CrossRef]

122. Blagitko-Dorfs, N.; Schlosser, P.; Greve, G.; Pfeifer, D.; Meier, R.; Baude, A.; Brocks, D.; Plass, C.; Lübbert, M. Combination treatment of acute myeloid leukemia cells with DNMT and HDAC inhibitors: Predominant synergistic gene downregulation associated with gene body demethylation. Leukemia 2019, 33, 945-956. [CrossRef]

123. Ocio, E.M.; Herrera, P.; Olave, M.T.; Castro, N.; Perez-Simon, J.A.; Brunet, S.; Oriol, A.; Mateo, M.; Sanz, M.-A.; Lopez, J.; et al. Panobinostat as part of induction and maintenance for elderly patients with newly diagnosed acute myeloid leukemia: Phase $\mathrm{Ib} / \mathrm{II}$ panobidara study. Haematologica. 2015, 100, 1294-1300. [CrossRef]

124. Bug, G.; Burchert, A.; Wagner, E.M.; Kroger, N.; Berg, T.; Guller, S.; Metzelder, S.K.; Wolf, A.; Hunecke, S.; Bader, P.; et al. Phase I/II study of the deacetylase inhibitor panobinostat after allogeneic stem cell transplantation in patients with high-risk MDS or AML (PANOBEST trial). Leukemia 2017, 31, 2523-2525. [CrossRef]

125. DeAngelo, D.J.; Spencer, A.; Bhalla, K.N.; Prince, H.M.; Fischer, T.; Kindler, T.; Giles, F.J.; Scott, J.W.; Parker, K.; Liu, A.; et al Phase Ia/II, two-arm, open-label, dose-escalation study of oral panobinostat administered via two dosing schedules in patients with advanced hematologic malignancies. Leukemia 2013, 27, 1628-1636. [CrossRef]

126. Giles, F.; Fischer, T.; Cortes, J.; Garcia-Manero, G.; Beck, J.; Ravandi, F.; Masson, E.; Rae, P.; Laird, G.; Sharma, S.; et al. A phase I study of intravenous LBH589, a novel cinnamic hydroxamic acid analogue histone deacetylase inhibitor, in patients with refractory hematologic malignancies. Clin. Cancer Res. 2006, 12, 4628-4635. [CrossRef]

127. Govindaraj, C.; Tan, P.; Walker, P.; Wei, A.; Spencer, A.; Plebanski, M. Reducing TNF receptor 2+ regulatory T cells via the combined action of azacitidine and the HDAC inhibitor, panobinostat for clinical benefit in acute myeloid leukemia patients. Clin. Cancer Res. 2014, 20, 724-735. [CrossRef] [PubMed]

128. Tao, R.; de Zoeten, E.F.; Ozkaynak, E.; Chen, C.; Wang, L.; Porrett, P.M.; Li, B.; Turka, L.A.; Olson, E.N.; Greene, M.I.; et al. Deacetylase inhibition promotes the generation and function of regulatory T cells. Nat. Med. 2007, 13, 1299-1307. [CrossRef] [PubMed]

129. Hancock, W.W.; Akimova, T.; Beier, U.H.; Liu, Y.; Wang, L. HDAC inhibitor therapy in autoimmunity and transplantation. Ann. Rheum. Dis. 2012, 71, 46-54. [CrossRef]

130. Wieduwilt, M.J.; Pawlowska, N.; Thomas, S.; Olin, R.; Logan, A.C.; Damon, L.E.; Martin, T.; Kang, M.; Sayre, P.H.; Boyer, W.; et al. Histone deacetylase inhibition with panobinostat combined with intensive induction chemotherapy in older patients with acute myeloid leukemia: Phase I study results. Clin. Cancer Res. 2019, 25, 4917-4923. [CrossRef] [PubMed] 
131. Kalin, B.; van Norden, Y.; van Gelder, M.; Breems, D.; Maertens, J.; Jongen-Lavrencic, M.; Broers, A.E.C.; Braakman, E.; Grob, T.; Zeijlemaker, W.; et al. Panobinostat and decitabine prior to donor lymphocyte infusion in allogeneic stem cell transplantation. Blood Adv. 2020, 4, 4430-4437. [CrossRef] [PubMed]

132. Garcia-Manero, G.; Sekeres, M.A.; Egyed, M.; Breccia, M.; Graux, C.; Cavenagh, J.D.; Salman, H.; Illes, A.; Fenaux, P.; DeAngelo, D.J.; et al. A phase $1 \mathrm{~b} / 2 \mathrm{~b}$ multicenter study of oral panobinostat plus azacitidine in adults with MDS, CMML or AML with $\leq 30 \%$ blasts. Leukemia 2017, 31, 2799-2806. [CrossRef]

133. Arber, D.A.; Orazi, A.; Hasserjian, R.; Thiele, J.; Borowitz, M.J.; Le Beau, M.M.; Bloomfield, C.D.; Cazzola, M.; Vardiman, J.W. The 2016 revision to the World Health Organization classification of myeloid neoplasms and acute leukemia. Blood 2016, 127, 2391-2405. [CrossRef] [PubMed]

134. Döhner, H.; Estey, E.; Grimwade, D.; Amadori, S.; Appelbaum, F.R.; Büchner, T.; Dombret, H.; Ebert, B.L.; Fenaux, P.; Larson, R.A.; et al. Diagnosis and management of AML in adults: 2017 ELN recommendations from an international expert panel. Blood 2017, 129, 424-447. [CrossRef] [PubMed]

135. Craddock, C.; Labopin, M.; Robin, M.; Finke, J.; Chevallier, P.; Yakoub-Agha, I.; Bourhis, J.H.; Sengelov, H.; Blaise, D.; Luft, T.; et al. Clinical activity of azacitidine in patients who relapse after allogeneic stem cell ransplantation for acute myeloid leukemia. Haematologica 2016, 101, 879-883. [CrossRef]

136. Bruserud, Ø.; Stapnes, C.I.; Ersvaer, E.; Gjertsen., B.T.; Ryningen, A. Histone deacetylase inhibitors in cancer treatment: A review of the clinical toxicity and the modulation of gene expression in cancer cell. Curr. Pharm. Biotechnol. 2007, 8, 388-400. [CrossRef] [PubMed]

137. Lubbert, M.; Bertz, H.; Wasch, R.; Marks, R.; Ruter, B.; Claus, R.; Finke, J. Efficacy of a 3-day, low-dose treatment with 5-azacytidine followed by donor lymphocyte infusions in older patients with acute myeloid leukemia or chronic myelomonocytic leukemia relapsed after allografting. Bone Marrow. Transplant. 2010, 45, 627-632. [CrossRef] [PubMed]

138. Fredly, H.; Stapnes Bjornsen, C.; Gjertsen, B.T.; Bruserud, Ø. Combination of the histone deacetylase inhibitor valproic acid with oral hydroxyurea or 6-mercaptopurin can be safe and effective in patients with advanced acute myeloid leukaemia-a report of five cases. Hematology 2010, 15, 338-343. [CrossRef]

139. Grishina, O.; Schmoor, C.; Döhner, K.; Hackanson, B.; Lubrich, B.; May, A.M.; Cieslik, C.; Müller, M.J.; Lübbert, M. DECIDER: Prospective randomized multicenter phase II trial of low-dose decitabine (DAC) administered alone or in combination with the histone deacetylase inhibitor valproic acid (VPA) and all-trans retinoic acid (ATRA) in patients $>60$ years with acute myeloid leukemia who are ineligible for induction chemotherapy. BMC Cancer 2015, 15, 430.

140. Garcia-Manero, G.; Kantarjian, H.M.; Sanchez-Gonzalez, B.; Yang, H.; Rosner, G.; Verstovsek, S.; Rytting, M.; Wierda, W.G.; Ravandi, F.; Koller, C.; et al. Phase 1/2 study of the combination of 5-aza-2'-deoxycytidine with valproic acid in patients with leukemia. Blood 2006, 108, 3271-3279. [CrossRef] [PubMed]

141. Blum, W.; Klisovic, R.B.; Hackanson, B.; Liu, Z.; Liu, S.; Devine, H.; Vukosavljevic, T.; Huynh, L.; Lozanski, G.; Kefauver, C.; et al. Phase I study of decitabine alone or in combination with valproic acid in acute myeloid leukemia. J. Clin. Oncol. 2007, 25, 3884-3891. [CrossRef] [PubMed]

142. Kuendgen, A.; Gattermann, N. Valproic acid for the treatment of myeloid malignancies. Cancer 2007, 110, 943-954. [CrossRef] [PubMed]

143. Xuan, L.; Liu, Q. Maintenance therapy in acute myeloid leukemia after allogeneic hematopoietic stem cell transplantation. J. Hematol. Oncol. 2021, 14, 4. [CrossRef] [PubMed]

144. Schroeder, T.; Rautenberg, C.; Haas, R.; Germing, U.; Kobbe, G. Hypomethylating agents for treatment and prevention of relapse after allogeneic blood stem cell transplantation. Int. J. Hematol. 2018, 107, 138-150. [CrossRef]

145. Czibere, A.; Bruns, I.; Kröger, N.; Platzbecker, U.; Lind, J.; Zohren, F.; Fenk, R.; Germing, U.; Schröder, T.; Gräf, T.; et al. 5-Azacytidine for the treatment of patients with acute myeloid leukemia or myelodysplastic syndrome who relapse after allo-SCT: A retrospective analysis. Bone Marrow. Transpl. 2010, 45, 872-876. [CrossRef]

146. Steinmann, J.; Bertz, H.; Wäsch, R.; Marks, R.; Zeiser, R.; Bogatyreva, L.; Finke, J.; Lübbert, M. 5-Azacytidine and DLI can induce long-term remissions in AML patients relapsed after allograft. Bone Marrow. Transpl. 2015, 50, 690-695. [CrossRef]

147. Tessoulin, B.; Delaunay, J.; Chevallier, P.; Loirat, M.; Ayari, S.; Peterlin, P.; Le Gouill, S.; Gastinne, T.; Moreau, P.; Mohty, M.; et al. Azacitidine salvage therapy for relapse of myeloid malignancies following allogeneic hematopoietic SCT. Bone Marrow Transpl. 2014, 49, 567-571. [CrossRef]

148. Schroeder, T.; Rachlis, E.; Bug, G.; Stelljes, M.; Klein, S.; Steckel, N.K.; Wolf, D.; Ringhoffer, M.; Czibere, A.; Nachtkamp, K.; et al Treatment of acute myeloid leukemia or myelodysplastic syndrome relapse after allogeneic stem cell transplantation with azacitidine and donor lymphocyte infusions-A retrospective multicenter analysis from the German Cooperative Transplant Study Group. Biol. Blood Marrow. Transpl. 2015, 21, 653-660. [CrossRef]

149. Woo, J.; Deeg, H.J.; Storer, B.; Yeung, C.; Fang, M.; Mielcarek, M.; Scott, B.L. Factors determining responses to azacitidine in patients with myelodysplastic syndromes and acute myeloid leukemia with early post-transplantation relapse: A prospective trial. Biol. Blood Marrow. Transpl. 2017, 23, 176-179. [CrossRef]

150. Sommer, S.; Cruijsen, M.; Claus, R.; Bertz, H.; Wäsch, R.; Marks, R.; Zeiser, R.; Bogatyreva, L.; Blijlevens, N.M.A.; May, A.; et al. Decitabine in combination with donor lymphocyte infusions can induce remissions in relapsed myeloid malignancies with higher leukemic burden after allogeneic hematopoietic cell transplantation. Leuk. Res. 2018, 72, 20-26. [CrossRef] 
151. Schroeder, T.; Rautenberg, C.; Krüger, W.; Platzbecker, U.; Bug, G.; Steinmann, J.; Klein, S.; Hopfer, O.; Nachtkamp, K.; Kondakci, M.; et al. Treatment of relapsed AML and MDS after allogeneic stem cell transplantation with decitabine and DLI-a retrospective multicenter analysis on behalf of the German Cooperative Transplant Study Group. Ann. Hematol. 2018, 97, 335-342. [CrossRef] [PubMed]

152. Craddock, C.; Slade, D.; De Santo, C.; Wheat, R.; Ferguson, P.; Hodgkinson, A.; Brock, K.; Cavenagh, J.; Ingram, W.; Dennis, M.; et al. Combination lenalidomide and azacitidine: A novel salvage therapy in patients who relapse after allogeneic stem-cell transplantation for acute myeloid leukemia. J. Clin. Oncol. 2019, 37, 580-588. [CrossRef] [PubMed]

153. Thakar, M.S.; Forman, S.J. ASH evidence-based guidelines: Is there a role for second allogeneic transplant after relapse? Hematol. Am. Soc. Hematol. Educ. Program 2009, 414-418. [CrossRef]

154. El-Jawahri, A.R.; Abel, G.A.; Steensma, D.P.; LeBlanc, T.W.; Fathi, A.T.; Graubert, T.A.; DeAngelo, D.J.; Wadleigh, M.; Ballen, K.K.; Foster, J.E.; et al. Health care utilization and end-of-life care for older patients with acute myeloid leukemia. Cancer 2015, 121, 2840-2848. [CrossRef]

155. LeBlanc, T.W.; Wolf, S.P.; El-Jawahri, A.; Davis, D.M.; Locke, S.C.; Abernethy, A. Symptom burden, quality of life, and distress in acute myeloid leukemia patients receiving induction chemotherapy: Results of a prospective electronic patient-reported outcomes study. Blood 2015, 126, 4496. [CrossRef]

156. Slavin, S.D.; Fenech, A.; Jankowski, A.L.; Abel, G.A.; Brunner, A.M.; Steensma, D.P.; Fathi, A.T.; DeAngelo, D.J.; Wadleigh, M.; Hobbs, G.S.; et al. Outcomes for older adults with acute myeloid leukemia after an intensive care unit admission. Cancer 2019, 125, 3845-3852. [CrossRef] [PubMed]

157. Cheng, H.W.; Li, C.W.; Chan, K.Y.; Au, H.Y.; Chan, P.F.; Sin, Y.C.; Szeto, Y.; Sham, M.K. End-of-life characteristics and palliative care provision for elderly patients suffering from acute myeloid leukemia. Support Care Cancer 2015, 23, 111-116. [CrossRef]

158. Lübbert, M.; Suciu, S.; Baila, L.; Rüter, B.H.; Platzbecker, U.; Giagounidis, A.; Selleslag, D.; Labar, B.; Germing, U.; Salih, H.R.; et al. Low-dose decitabine versus best supportive care in elderly patients with intermediate- or high-risk myelodysplastic syndrome (MDS) ineligible for intensive chemotherapy: Final results of the randomized phase III study of the European Organisation for Research and Treatment of Cancer Leukemia Group and the German MDS Study Group. J. Clin. Oncol. 2011, 29, $1987-1996$.

159. Kornblith, A.B.; Herndon, J.E., II; Silverman, L.R.; Demakos, E.P.; Odchimar-Reissig, R.; Holland, J.F.; Powell, B.L.; DeCastro, C.; Ellerton, J.; Larson, R.A.; et al. Impact of azacytidine on the quality of life of patients with myelodysplastic syndrome treated in a randomized phase III trial: A cancer and leukemia group B study. J. Clin. Oncol. 2002, 20, 2441-2452. [CrossRef]

160. Bosshard, R.; O’Reilly, K.; Ralston, S.; Chadda, S.; Cork, D. Systematic reviews of economic burden and health-related quality of life in patients with acute myeloid leukemia. Cancer Treat. Rev. 2018, 69, 224-232. [CrossRef]

161. Korol, E.E.; Wang, S.; Johnston, K.; Ravandi-Kashani, F.; Levis, M.; van Nooten, F. Health-related quality of life of patients with acute myeloid leukemia: A systematic literature. Rev. Oncol. Ther. 2017, 5, 1-16. [CrossRef] [PubMed]

162. Schumacher, A.; Kessler, T.; Buchner, T.; Wewers, D.; van de Loo, J. Quality of life in adult patients with acute myeloid leukemia receiving intensive and prolonged chemotherapy_A longitudinal study. Leukemia 1998, 12, 586-592. [CrossRef] [PubMed]

163. Leunis, A.; Redekop, W.K.; Uyl-de Groot, C.A.; Lowenberg, B. Impaired health-related quality of life in acute myeloid leukemia survivors: A single-center study. Eur. J. Haematol. 2014, 93, 198-206. [CrossRef]

164. Messerer, D.; Engel, J.; Hasford, J.; Schaich, M.; Ehninger, G.; Sauerland, C.; Büchner, T.; Schumacher, A.; Krahl, R.; Niederwieser, D.; et al. Impact of different post-remission strategies on quality of life in patients with acute myeloid leukemia. Haematologica 2008, 93, 826-833. [CrossRef]

165. Gupta, V.; Panzarella, T.; Li, L.; Khan, J.; Sharma, A.; Lipton, J.H.; Kuruvilla, J.; Messner, H.; Alibhai, S.M. A prospective study comparing the outcomes and health-related quality of life in adult patients with myeloid malignancies undergoing allogeneic transplantation using myeloablative or reduced-intensity conditioning. Biol. Blood Marrow. Transpl. 2012, 18, 113-124. [CrossRef]

166. Watson, M.; Buck, G.; Wheatley, K.; Homewood, J.R.; Goldstone, A.H.; Rees, J.K.; Burnett, A.K. Adverse impact of bone marrow transplantation on quality of life in acute myeloid leukaemia patients: Analysis of the UK Medical Research Council AML 10 Trial. Eur. J. Cancer 2004, 40, 971-978. [CrossRef]

167. Kurosawa, S.; Yamaguchi, T.; Mori, T.; Kanamori, H.; Onishi, Y.; Emi, N.; Fujisawa, S.; Kohno, A.; Nakaseko, C.; Saito, B.; et al. Patient-reported quality of life after allogeneic hematopoietic cell transplantation or chemotherapy for acute leukemia. Bone Marrow Transpl. 2015, 50, 1241-1249. [CrossRef]

168. Bazarbachi, A.H.; Al Hamed, R.; Malard, F.; Mohty, M.; Bazarbachi, A. Allogeneic transplant for FLT3-ITD mutated AML: A focus on FLT3 inhibitors before, during, and after transplant. Ther. Adv. Hematol. 2019, 10. [CrossRef]

169. Sockel, K.; Bornhaeuser, M.; Mischak-Weissinger, E.; Trenschel, R.; Wermke, M.; Unzicker, C.; Kobbe, G.; Finke, J.; Germing, U.; Mohr, B.; et al. Lenalidomide maintenance after allogeneic HSCT seems to trigger acute graft-versus-host disease in patients with high-risk myelodysplastic syndromes or acute myeloid leukemia and del(5q): Results of the LENAMAINT trial. Haematologica 2012, 97, e34-e35. [CrossRef] [PubMed]

170. El-Cheikh, J.; Massoud, R.; Fares, E.; Kreidieh, N.; Mahfouz, R.; Charafeddine, M.; Kharfan-Dabaja, M.A.; Bazarbachi, A. Low-dose 5-azacytidine as preventive therapy for relapse of AML and MDS following allogeneic HCT. Bone Marrow Transpl. 2017, 52, 918-921. [CrossRef] [PubMed] 
171. De Lima, M.; Giralt, S.; Thall, P.F.; de Padua Silva, L.; Jones, R.B.; Komanduri, K.; Braun, T.M.; Nguyen, H.Q.; Champlin, R.; Garcia-Manero, G. Maintenance therapy with low-dose azacitidine after allogeneic hematopoietic stem cell transplantation for recurrent acute myelogenous leukemia or myelodysplastic syndrome: A dose and schedule finding study. Cancer 2010, 116, 5420-5431. [CrossRef]

172. De Lima, M.; Oran, B.; Champlin, R.E.; Papadopoulos, E.B.; Giralt, S.A.; Scott, B.L.; William, B.M.; Hetzer, J.; Laille, E.; Hubbell, B.; et al. CC-486 maintenance after stem cell transplantation in patients with acute myeloid leukemia or myelodysplastic syndromes. Biol. Blood Marrow Transpl. 2018, 24, 2017-2024. [CrossRef] [PubMed]

173. Pusic, I.; Choi, J.; Fiala, M.A.; Gao, F.; Holt, M.; Cashen, A.F.; Vij, R.; Abboud, C.N.; Stockerl-Goldstein, K.E.; Jacoby, M.A.; et al. Maintenance therapy with decitabine after allogeneic stem cell transplantation for acute myelogenous leukemia and myelodysplastic syndrome. Biol. Blood Marrow Transpl. 2015, 21, 1761-1769. [CrossRef] [PubMed]

174. Oshikawa, G.; Kakihana, K.; Saito, M.; Aoki, J.; Najima, Y.; Kobayashi, T.; Doki, N.; Sakamaki, H.; Ohashi, K. Post-transplant maintenance therapy with azacitidine and gemtuzumab ozogamicin for high-risk acute myeloid leukaemia. Br. J. Haematol. 2015, 169, 756-759. [CrossRef]

175. Schmid, C.; Labopin, M.; Schaap, N.; Veelken, H.; Schleuning, M.; Stadler, M.; Finke, J.; Hurst, E.; Baron, F.; Ringden, O.; et al. Prophylactic donor lymphocyte infusion after allogeneic stem cell transplantation in acute leukaemia-A matched pair analysis by the Acute Leukaemia Working Party of EBMT. Br. J. Haematol. 2019, 184, 782-787. [CrossRef]

176. Platzbecker, U.; Middeke, J.M.; Sockel, K.; Herbst, R.; Wolf, D.; Baldus, C.D.; Oelschlägel, U.; Mütherig, A.; Fransecky, L.; Noppeney, R.; et al. Measurable residual disease-guided treatment with azacitidine to prevent haematological relapse in patients with myelodysplastic syndrome and acute myeloid leukaemia (RELAZA2): An open-label, multicentre, phase 2 trial. Lancet Oncol. 2018, 19, 1668-1679. [CrossRef]

177. Platzbecker, U.; Wermke, M.; Radke, J.; Oelschlaegel, U.; Seltmann, F.; Kiani, A.; Klut, I.M.; Knoth, H.; Röllig, C.; Schetelig, J.; et al. Azacitidine for treatment of imminent relapse in MDS or AML patients after allogeneic HSCT: Results of the RELAZA trial. Leukemia 2012, 26, 381-389. [CrossRef]

178. Liu, N.; Wang, C.; Wang, L.; Gao, L.; Cheng, H.; Tang, G.; Hu, X.; Wang, J. Valproic acid enhances the antileukemic effect of cytarabine by triggering cell apoptosis. Int. J. Mol. Med. 2016, 37, 1686-1696. [CrossRef]

179. Xie, C.; Edwards, H.; Xu, X.; Zhou, H.; Buck, S.A.; Stout, M.L.; Yu, Q.; Rubnitz, J.E.; Matherly, L.H.; Taub, J.W.; et al. Mechanisms of synergistic antileukemic interactions between valproic acid and cytarabine in pediatric acute myeloid leukemia. Clin. Cancer Res. 2010, 16, 5499-5510. [CrossRef]

180. Leitch, C.; Osdal, T.; Andresen, V.; Molland, M.; Kristiansen, S.; Nguyen, X.N.; Bruserud, Ø.; Gjertsen, B.T.; McCormack, E. Hydroxyurea synergizes with valproic acid in wild-type p53 acute myeloid leukaemia. Oncotarget 2016, 7, 8105-8118. [CrossRef]

181. Heo, S.K.; Noh, E.K.; Yoon, D.J.; Jo, J.C.; Park, J.H.; Kim, H. Dasatinib accelerates valproic acid-induced acute myeloid leukemia cell death by regulation of differentiation capacity. PLoS ONE 2014, 9, e98859. [CrossRef]

182. McCormack, E.; Haaland, I.; Venås, G.; Forthun, R.B.; Huseby, S.; Gausdal, G.; Knappskog, S.; Micklem, D.R.; Lorens, J.B.; Bruserud, $\varnothing$; et al. Synergistic induction of p53 mediated apoptosis by valproic acid and nutlin-3 in acute myeloid leukemia. Leukemia 2012, 26, 910-917. [CrossRef] [PubMed]

183. Nie, D.; Huang, K.; Yin, S.; Li, Y.; Xie, S.; Ma, L.; Wang, X.; Wu, Y.; Xiao, J. Synergistic/additive interaction of valproic acid with bortezomib on proliferation and apoptosis of acute myeloid leukemia cells. Leuk. Lymphoma 2012, 53, 2487-2495. [CrossRef]

184. Wang, A.H.; Wei, L.; Chen, L.; Zhao, S.Q.; Wu, W.L.; Shen, Z.X.; Li, J.M. Synergistic effect of bortezomib and valproic acid treatment on the proliferation and apoptosis of acute myeloid leukemia and myelodysplastic syndrome cells. Ann. Hematol. 2011, 90, 917-931. [CrossRef] [PubMed]

185. Xie, C.; Edwards, H.; Lograsso, S.B.; Buck, S.A.; Matherly, L.; Taub, J.W.; Ge, Y. Valproic acid synergistically enhances the cytotoxicity of clofarabine in pediatric acute myeloid leukemia cells. Pediatr. Blood Cancer 2012, 59, 1245-1251. [CrossRef]

186. Stahl, M.; Gore, S.D.; Vey, N.; Prebet, T. Lost in translation? Ten years of development of histone deacetylase inhibitors in acute myeloid leukemia and myelodysplastic syndromes. Expert Opin. Investig. Drugs 2016, 25, 307-317. [CrossRef] [PubMed]

187. Morabito, F.; Voso, M.T.; Hohaus, S.; Gentile, M.; Vigna, E.; Recchia, A.G.; Iovino, L.; Benedetti, E.; Lo-Coco, F.; Galimberti, S. Panobinostat for the treatment of acute myelogenous leukemia. Expert Opin. Investig. Drugs 2016, 25, 1117-1131. [CrossRef]

188. Ungerstedt, J.S. Epigenetic modifiers in myeloid malignancies: The role of histone deacetylase inhibitors. Int. J. Mol. Sci. 2018, 19, 3091. [CrossRef]

189. Qin, H.T.; Li, H.Q.; Liu, F. Selective histone deacetylase small molecule inhibitors: Recent progress and perspectives. Expert Opin. Ther. Pat. 2017, 27, 621-636. [CrossRef]

190. Cengiz Seval, G.; Beksac, M. A comparative safety review of histone deacetylase inhibitors for the treatment of myeloma. Expert Opin. Drug Saf. 2019, 18, 563-571. [CrossRef]

191. Allen, P.B.; Lechowicz, M.J. Hematologic toxicity is rare in relapsed patients treated with belinostat: A systematic review of belinostat toxicity and safety in peripheral T-cell lymphomas. Cancer Manag. Res. 2018, 10, 6731-6742. [CrossRef] [PubMed]

192. Leufven, E.; Bruserud, Ø. Immunosuppression and immunotargeted therapy in acute myeloid leukemia-The potential use of checkpoint inhibitors in combination with other treatments. Curr. Med. Chem. 2019, 26, 5244-5261. [CrossRef] [PubMed]

193. Sterling, C.; Webster, J. Harnessing the immune system after allogeneic stem cell transplant in acute myeloid leukemia. Am. J. Hematol. 2020, 95, 529-547. [CrossRef] [PubMed] 
194. Merryman, R.W.; Castagna, L.; Giordano, L.; Ho, V.T.; Corradini, P.; Guidetti, A.; Casadei, B.; Bond, D.A.; Jaglowski, S.; Spinner, M.A.; et al. Allogeneic transplantation after PD-1 blockade for classic Hodgkin lymphoma. Leukemia 2021. Epub ahead of print. [CrossRef] [PubMed]

195. Advani, A.S.; Tse, W.; Li, H.; Jia, X.; Elson, P.; Cooper, B.; Ali-Osman, F.; Park, J.; Rao, A.V.; Rizzieri, D.A.; et al. A Phase II trial of imatinib mesylate as maintenance therapy for patients with newly diagnosed c-kit-positive acute myeloid leukemia. Clin. Lymphoma Myeloma Leuk. 2021, 21, 113-118. [CrossRef]

196. Chang Muñoz, M.; Murphy, J.A.; Wolff, J.E.; Jonas, B.A. Prolonged response of a patient with relapsed acute myeloid leukemia to a novel oral bromodomain extraterminal inhibitor (BETi). Case Rep. Hematol. 2020, 2020, 8830123.

197. DiNardo, C.D.; Maiti, A.; Rausch, C.R.; Pemmaraju, N.; Naqvi, K.; Daver, N.G.; Kadia, T.M.; Borthakur, G.; Ohanian, M.; Alvarado, Y.; et al. 10-day decitabine with venetoclax for newly diagnosed intensive chemotherapy ineligible, and relapsed or refractory acute myeloid leukaemia: A single-centre, phase 2 trial. Lancet. Haematol. 2020, 7, e724-e736. [CrossRef] 